\title{
Medina and Mecca Revisited
}

\section{The Manuscripts of the Dalāil al-Khayrāt by al-Ğazūlì and Their Ornamental Addition}

\author{
Jan Just Witkam | ORCID: 0000-0002-6563-4288 \\ Leiden University Institute for Area Studies (LIAS), Leiden, The Netherlands \\ j.j.witkam@hum.leidenuniv.nl
}

\begin{abstract}
The illustrations of Medina and Mecca in al-Ǧazūlì's prayer book Dalä̉il al-Khayrāt have drawn the attention of many scholars, who have come up with different interpretations. In the present article, a subgroup within the Maghribi manuscripts of that text is defined for the first time: luxury manuscripts that date from the $11-12$ th $/ 17-18$ th centuries and that were mostly produced for important owners, certainly in Morocco, possibly in other parts of the Magrib. The manuscripts in this subgroup have an illustrated and illuminated addition that physically precedes the text of Dalāil al-Khayrāt, but that does not belong to the text of the prayer book. In the present article that addition is for the first time identified as such and described. A small corpus has been assembled and, by way of example, the article contains a detailed description of two manuscripts belonging to that newly defined subgroup: $\mathrm{Ms}$ Paris, Bibliothèque nationale de France, Arabe 6983, and Ms Berlin, Staatsbibliothek, Or. oct. 240.
\end{abstract}

\section{Keywords}

Medina - Mecca - Dalāil al-Khayrāt - al-Jazuli - illustrations - miniatures - holy places - Morocco - Maghreb - Sufism - pilgrimage - Islamic manuscripts 
The great number of manuscripts that exist of al-Ǧazūlī's Dalāil al-Khayrāt, the popular prayer book by the Moroccan mystic and activist Muhammad b. Sulaymān al-Ǧazūlī (d. 870/1465), ${ }^{3}$ shows that many pious copyists, miniaturists, illuminators, readers, teachers, commentators, glossators, and patrons have been active in producing and transmitting what has become one of the most popular prayer books of the Sunni world. There does not exist a critical edition of the text, and for practical reasons I consider the text that is included in Mațāli al-Masarrāt bi-Ğalä’ Daläil al-Khayrāt, the running commentary by al-Fāsī (d. 1109/1697-1698) as the vulgate version. ${ }^{4}$ While preparing my contribution to the symposium 'Theoretical Approaches to the Transmission and Edition of Oriental Manuscripts', to be held in Istanbul in March 28-30, 2001, ${ }^{5}$ I had assembled all manuscripts of the Daläil al-Khayrāt, that I could find in the collections of Leiden University Library. I do not think that ever before or since, such a great number from so many different origins of the manuscripts of this text had been together on one table. In all, they were thirty-four volumes that originated from most regions of the Sunni Islamic world, from the Maghrib and West Africa to as far away as Indonesia. The dated manuscripts

1 Submitted in an earlier version on 23 June 2020. Accepted for publication on 6 October 2020 .

2 Acknowledgment. I am grateful to the organizers of the al-Ǧazūlī conference in The Metropolitan Museum of Art, New York, 17-18 May 2019, for inviting me to participate.

3 This is the commonly accepted year of demise of al-Ǧazūlī.

4 I am grateful to Prof. Léon Buskens, Rabat, for providing me at short notice with a copy of an edition of al-Fāsī's Mațāli' al-Masarrāt.

5 My presentation appeared in the symposium's proceedings: 'The Battle of the Images. Mecca vs. Medina in the Iconography of the Manuscripts of al-Jazūli’s Daläil al-Khayrāt', in Judith Pfeiffer \& Manfred Kropp (eds.), Technical Approaches to the Transmission and Edition of Oriental Manuscripts = Beiruter Texte und Studien, No. 111 (Beirut: Orient Institut, 2007), pp. 67-82 (text), 295-300 (illustrations). I had submitted it in 2002 but it was only published five years later. My monograph in Dutch, Vroomheid en activisme in een islamitisch gebedenboek. De geschiedenis van de Dalāil al-Khayrāt van al-Ğazūlī. Leiden: Legatum Warnerianum, appeared in 2002 .

I am most grateful to Dr. Hiba Abid, who, on December 3, 2019, and on March 5, 202O, placed two (out of four) volumes of her as yet unpublished $\mathrm{PhD}$ thesis of 2017 at my disposal: École Pratique des Hautes Études. Les Dalāil al-Khayrāt d'al-Jazūlī (m. 869/1465). La tradition manuscrite d'un livre de prières soufi au Maghreb du X $X^{e} / X V I^{e}$ au XIII $/ X I X^{e}$ siècles. Thèse de doctorat de Codicologie et d'Histoire de l' art islamiques. Sous la direction de M. François Déroche, Professeur au Collège de France. Soutenue le 12 mai 2017. I received from her copies of vol. I (Texte) and vol. II (Catalogue des manuscrits). A third volume containing illustrations apparently exists, as well as a fourth volume, but I have not seen these. 
in that corpus were of the period 1704-1888. Primarily, I wanted to study the book's illustrations. While thirty-four is quite a formidable number, it is in no way a representative sample for such a popular work as al-Ğazūli’s. ${ }^{6}$ They were a good start, however, and the ideas that I developed with them are still largely uncontested. Now, some twenty years later, after having seen hundreds of manuscripts of al-Ğazūlī's prayer book more, I feel able to elaborate further, on much larger samples, with an even more compelling argument about the shifts in the imagery in the manuscripts.

Already with my first sample of thirty-four manuscripts, it was clear to me that I could assume that there had been an historical development in the iconographic programme in the section of sifat al-rawda al-mubāraka, 'the Description of the Blessed Garden', as the grave of the Prophet Muhammad in the Great Mosque of Medina is called. I summarize my earlier findings, both based on assumptions, and on facts. It is a development in four stages:

1. The oldest manuscripts of Dalä'il al-Khayrāt were not illustrated. This is hypothetical. It is possible that the earliest copies already featured an image of the 'Blessed Garden', but we just do not know.

2. The Medinan single image of the burial chamber. This is the pictorial extension of the text in the introduction, șifat al-rawda al-mubāraka. It is the beginning of the pictorial tradition in the manuscripts of Daläil al-Khayrāt. The first five manuscripts in Abid's corpus, dated between 955-1035/1548-1628, are with the single illustration. ${ }^{7}$ It has remained in use for a long time, also outside the Maghrib, Ms Leiden Or. 7057a, for instance, dates from the 18th century and was copied in Banten, West Java; Ms Leiden Or. 22.958 originates from India and possibly dates from the 19th century. The commentary by al-Fāsī, which

6 As several friends were kind enough to point out. P.Sj. van Koningsveld (1943-2021) made this clear in a review of my Vroomheid: P.Sj. van Koningsveld, 'Puriteinen niet wars van plaatjes profeet. Studie naar afbeeldingen van Mohammed in gebedenboek', in: Mare di Libri, December 4, 2003, p. 6. Of course, with a popular text as the Dalä'il al-Khayrāt, any sample of manuscripts can hardly be representative.

7 Abid, Dalā'il, vol. II, pp. 7-15 (her Nos. D1-D5): Mss Rabat, Ḥasaniyya (Bibliothèque Royale) 3227 (dated 955/1548), see Abid, "The Birth of a Successful Prayer Book. The Manuscript Tradition of the Dalā'il al-Khayrāt in North Africa', in the present volume', fig. 3; Paris, BnF, Arabe 1181 (dated 1007/1599), see Abid, 'Birth', fig. 4; New York, Public Library, Arabic 5 (dated 1025/1616), see Abid, 'Birth', fig. 5; Paris, BNF, Arabe 1270 (dated 1029/1620); Paris, BnF, Arabe 1185 (dated 1035/1626). 
was written before 1109/1697-1698 (the year of its author's demise), shows this stage of the illustration programme of Daläil al-Khayrāt: the single Medinan image. ${ }^{8}$ The illustrations and text of the Mațālic al-Masarrāt have sometimes been included in copies of Daläil al-Khayrāt (figure 1). ${ }^{9}$

3. The Medinan double image of the burial chamber and the minbar. This is an expression of the hadith 'Whatever is between my grave and my pulpit, is a garden of Paradise'.

Sometimes the two images are combined into one illustration (as in figure 2), ${ }^{10}$ but usually the double image is given on two opposite pages (figure 3 ).

The simple heuristic principle that I developed in order to find the reason for the occurrence of the Medinan double image is this: an illustration refers to a passage in the text; if an illustration is not caused by a passage in the text, it is caused by a passage outside the text. In the case of the Medinan double illustration, this passage outside the text was the hadith: mā bayna qabri wa-minbarì rawda min riyāẹ al-ğanna. ${ }^{11}$ In a small number of manuscripts this

8 See on this commentary now also Guy Burak, 'Collating The Signs of Benevolent Deeds. Muḥammad Mahdī al-Fāsìs Commentary on Muhammad al-Jazūlī's Dalāil al-Khayrāt and Its Ottoman Readers', in: Philological Encounters 4 (2018), pp. 135-157.

For inclusion of images, see Ms Doha, Qațar National Library, No. 30003, a manuscript possibly from India, not dated, on f. 18a (figure 1). For inclusion of information from Mațālic al-Masarrät, see Ms Paris, BnF, Arabe 7170, a bilingual (Arabic and Persian) manuscript of Dalāil al-Khayrāt from Gujarat, India, dated Muḥarram 1188 (1774), on ff. $3 \mathrm{~b}-12 \mathrm{a}(D \bar{\imath} b \bar{a}-$ ğat Dalāil al-Khayrāt). That manuscript has a Mecca-Medina double image added to it, before the beginning of the Dībā ğa. Visual echos from al-Fāsì's commentary and also of alSamhūdī's (d. 911/1506) description of the Rawda, can be seen in glosses in Ms New York, Columbia University, Rare Book and Manuscript Library Or. 117, which is an annotated copy of the Daläil al-Khayrāt (ff. 2ob-21a) https://openn.library.upenn.edu/Data/oo32/ html/ms_or_117.html (accessed on 9 May 2021).

10 A North African manuscript dating from 1185 (1771-1772) with the two features combined into one image is MS Philadelphia, US, Library Company 69097 D, f. 13 b https://openn .library.upenn.edu/Data/oo12/html/69o97_d.html (accessed on 9 May 2021). It was originally purchased in $1876-1877$ in Algiers.

11 A corroboration of my heuristic principle can be seen in an illustration in Ms Paris, BnF, Arabe 1180, f. 1a (which is a single leaf which may have been added to that manuscript),

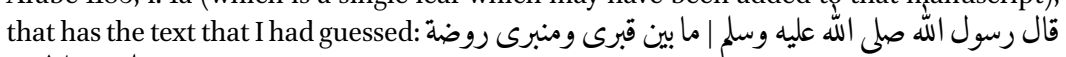
| This mä bayna ... tradition is also found in MS New York, TMMA 2017.131, f. 22a; Ms Paris, BnF, Arabe 6983 [Réserve 1517], f. 16a; Ms Rabat, Bibliothèque Hasaniya 12301, f. 29a, and possibly more. All these instances occur, however, in the 'ornamental addition', not in the text of the Daläil al-Khayrät itself. An expanded text in Ms Paris, BnF, Arabe 1192, f. 16a, makes explicit the occurrence of the image of the minbar, which usually is not mentioned in the text of the Daläil al-Khayrāt, but it does not refer to the $m \bar{a}$ bayna ... tradition. 


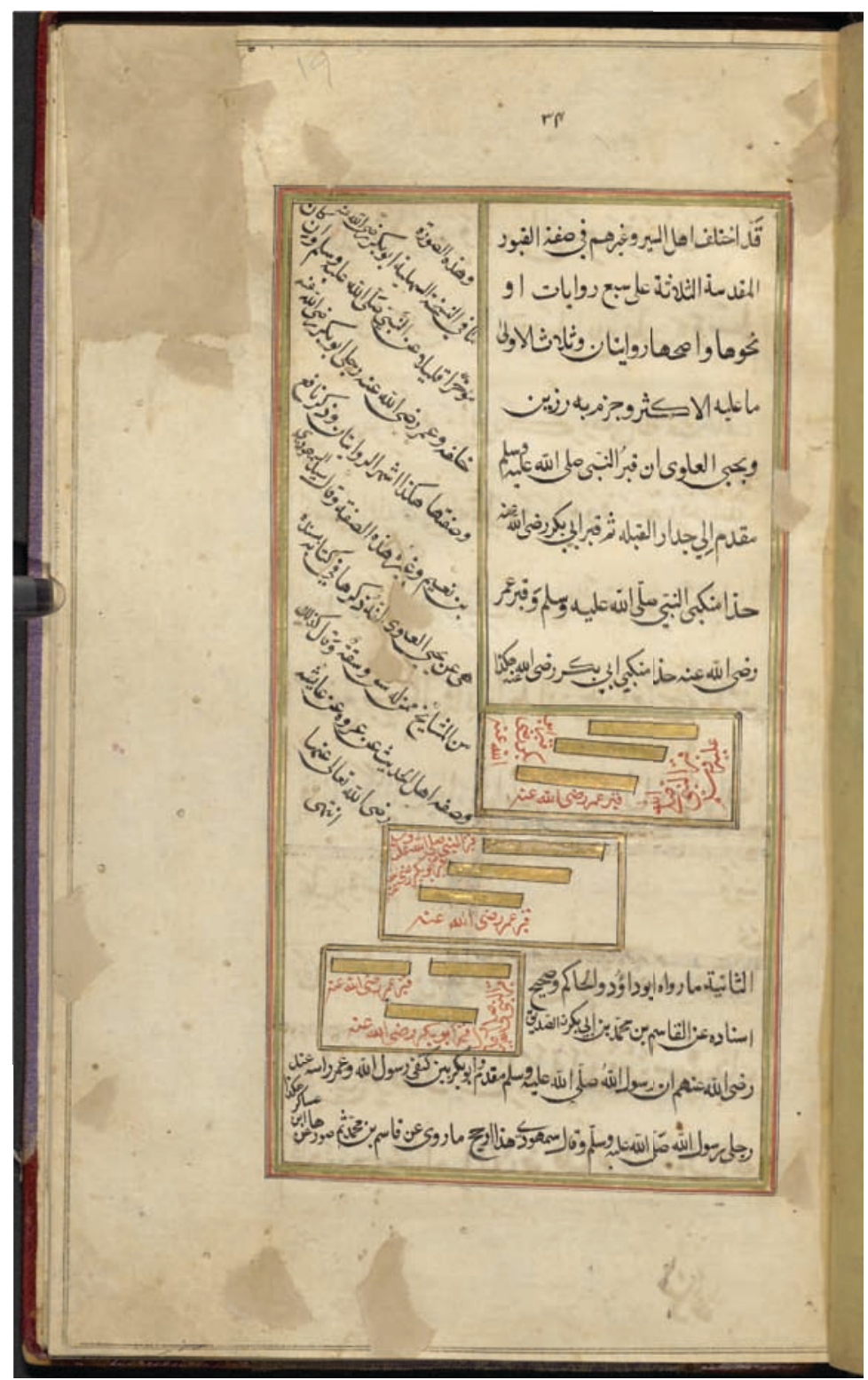

FIGURE 1 The possible positions of the graves in the Medinan burial chamber in the Prophet's mosque, as part of the description of the 'Blessed Garden'. Illustrated passage taken from a copy of Daläil al-Khayrāt, which was apparently influenced by a manuscript of al-Fāsī's Mațāli‘ al-Masarrāt

MS DOHA, QAṬAR NATIONAL LIBRARY, 30003, F. 18A (MODERN FOLIATION), POSSIBLY FROM INDIA, NOT DATED 


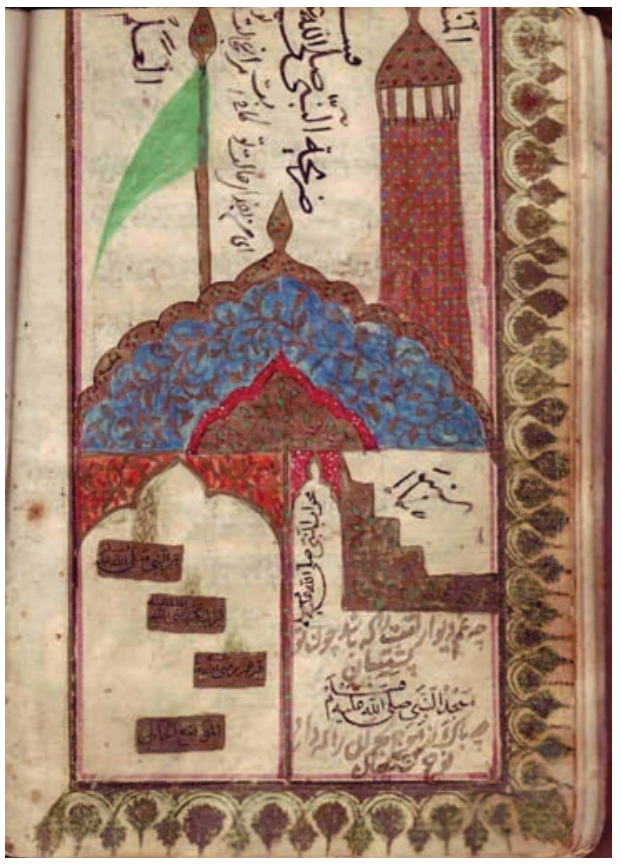

FIGURE 2

The rawda and the minbar combined into one miniature of the Prophet's mosque in Medina. The fourth tomb, that of Fātima, is also featured. In the background is a minaret in Bukhāran style. Illustration in a manuscript from Central Asia (13/19th century?) of Dalāil al-Khayrāt MS ISTANBUL, DR. ÖMER KOÇYIĞIT'S PRIVATE COLLECTION

implicit text has been made explicit, as I discovered when I was describing the Paris manuscripts of the Daläil al-Khayrät. ${ }^{12}$

Hiba Abid, in the meantime, has come with a narrative of her own about the development of iconographical elements in the Maghribi manuscripts of the Daläil al-Khayrät, that only partly overlaps mine, and in which my hypothesis, which was verified by the evidence of at least three manuscripts, was downgraded to a mere suggestion. ${ }^{13}$

4. The shift to the Mecca-Medina double image. The same heuristic principle that I developed to better comprehend the Medinan double image can be used for a better understanding of the shift from the Medinan double image (rawda and minbar) to the Mecca-Medina image. Unfortunately, we do not

12 In March 2005, while in Paris as an invited professor at the École des Hautes Études en Sciences Sociales (EHESS), I described the manuscripts of Dalä'il al-Khayrāt in the Bibliothèque nationale de France. These Parisian travel notes of 2005 are now in an advanced stage of editing. Hiba Abid has somehow been able to use an early version of my unpublished notes of 2005 for her thesis of 2017, at least she refers to them in her Daläil, volume 2, Catalogue de manuscrits several times: p. 10 (footnote 1), p. 123 (footnote 20).

13 Hiba Abid, 'Material Images and Mental Ziyāra: Depicting the Prophet's Grave in North African Devotional Books (Dalāil al-Khayrāt)', in: Journal of Material Cultures in the Muslim World 1 (2020), pp. 331-354, pp. 336-337. 


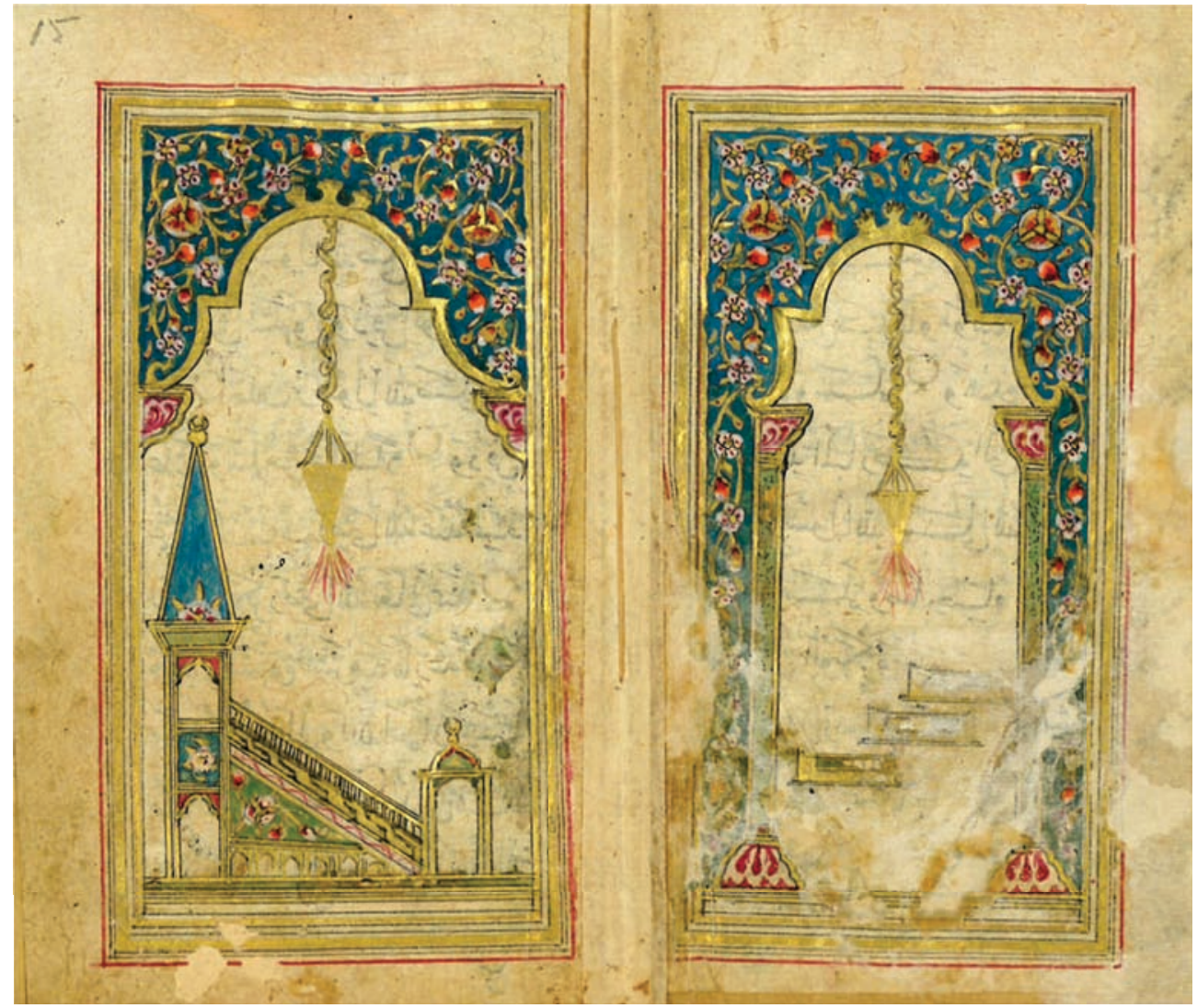

FIGURE 3 Double-page illustration of the Medinan sanctuary. On the right (f. 14b), the burial chamber with the three graves in a niche with a lamp. On the left, the minbar in a niche with lamp (f. 15a). Dated 1199 (1784-1785). From a manuscript of Ottoman origin MS LEIDEN, TER LUGT COLLECTION, NO. 49

have a well-studied corpus of non-Maghrib̄i manuscripts of Daläil al-Khayrāt. It is my impression, that from about the mid-12th/18th century, the Medinan double image in the text of Daläil al-Khayrät shifted to another combination of images: the Great Mosque of Mecca and the Prophet's Mosque in Medina in numerous different styles.

This is more than just a thematic shift. The Medinan double image suggested the burial chamber and the minbar to be within reach of hand, but in the Mecca-Medina double image the distance between the objects depicted and the believer has become much greater. Searching for an external explanation for the Meccan-Medinan double image, I came up with no less a text than the shahāda, the Muslim creed itself, the 'Two Words' in which both God and the Prophet are mentioned, reflecting Mecca with the Kaba as the House of God, 
and the Medinan mosque as 'the House of the Prophet'. That this is the case is evident and can easily be attested in numerous manuscripts of Dalä'il alKhayrät, but why it happened at the time it did, is less evident. Of course, the shahäda is always a relevant text, but why would it be depicted as the MeccaMedina double image only from about the mid-18th century onwards? Twenty years ago, I came up with a possible connection with the tenets of the Wahhabi movement, which for lack of a better theory is still a valid assumption. There may be other and more suitable explanations. To explore that road, we first need to have a corpus of relevant material. Indeed, as I have shown in the present article, with my definition of a group of luxury manuscripts within the Maghribi group containing an ornamental addition in no way challenges my earlier theories.

\section{The Ornamental Addition}

Writing in 2002, I was unaware of the existence of a subgroup of luxury manuscripts within the Maghribı manuscripts of Dalä'il al-Khayrāt. ${ }^{14}$ This group consists of luxury manuscripts made for important personalities. Except for their sumptuous execution throughout, textually speaking they are identical to the 'normal' manuscripts of the Dalä'il al-Khayrät, but with one exception. Their text is preceded by a number of features of text, calligraphy, illumination and illustration, all in line with the devotion of the Prophet Muhammad. That ornamental addition is not part of the vulgate text of the Daläil al-Khayrāt, it was only added to it in a limited number of cases. The ornamental addition consists of the following four features, not all of which are preserved in all manuscripts of the group:

- The pedigree of the Prophet Muhammad to Adam, combined with an enumeration of al-Ashara al-Mubashshara, the ten Companions who had been promised Paradise during their lifetime.

- A list of the twenty-one expeditions of the Prophet Muhammad.

- Topographical illustrations of the mosques of Mecca and Medina. Whether or not these two images together are meant as a pictorial expression of the shahäda is not indicated.

- Drawing of the sandal, $n a^{c}$, of the Prophet, usually placed on a double-page. Hiba Abid's unpublished catalogue gives a few references to manuscripts that

14 I simply had never seen one, and therefore none was represented in the corpus that I described in my Vroomheid of 2002. 
have this additional part. ${ }^{15}$ Van Koningsveld has come up with a few more, ${ }^{16}$ but neither scholar has identified the ornamental addition as a separate unit, that is as being not part of the Daläil al-Khayrāt proper. Abid connects the additional Mecca-Medina double image in this ornamental addition with the pilgrimage. As possible as that may seem, that does not explain the presence of the other elements in the additional pages, to wit the Prophet's pedigree, the enumeration of al-Ashara al-Mubashshara, the image of his sandal and the list of his expeditions. Their common denominator and their connection with the Dalāil al-Khayrāt is, of course, the devotion of the Prophet Muhammad, and none of these have a direct link with the pilgrimage.${ }^{17}$ Below follows a preliminary list of the manuscripts which are provided with the ornamental addition or elements thereof.

\subsection{Dated $1035\left(1625^{-1626)}\right.$}

Ms New York, Metropolitan Museum, 2017.301. The manuscript is incomplete at the beginning and only two leaves (now ff. 14-15) show elements of the ornamental addition, Mecca and Medina, with captions. The leaves are presently in disorder, it would seem. It is even possible that the volume is made-up from fragments coming from more than one codex. In the colophon (f. 124a) Muhammad b. Aḥmad b. 'Abd al-Raḥmān al-Riyāhī is mentioned copyist and Aḥmad b. Dirham al-Māliki as patron. ${ }^{18}$ Paleographically speaking, the person who wrote the colophon cannot have written the main text. Al-Riyāhī is apparently the head of the workshop in which this manuscript was produced. We may assume that the other special elements, to wit the calligraphies, illustrations and illuminations were made by others as well. The manuscript may have been produced by a team, the members of which divided their labour under the responsibility of 'copyist' al-Riyāhī. The physical architecture of the manuscript has not been investigated. ${ }^{19}$ Its red full-leather binding with flap is meant to make an Islamic

15 Abid, Dalä'il, vol. I, p. 259 and passim. The number may grow when more data on a corpus are collected. In a review of my Vroomheid, P.Sj. van Koningsveld in 'Puriteinen niet wars van plaatjes profeet' already mentions three more manuscripts that seem to belong to this same subgroup of luxury manuscripts of the Daläil al-Khayrāt.

16 The scant details of the three manuscripts mentioned by Van Koningsveld are repeated here without elaboration, except Ms Paris, Musée Quai Branly 74.1962.o.

17 Medina is not a destination of the obligatory pilgrimage, hağğ, but only the object of a recommended visit, ziyāra.

18 Reproduced as the frontispiece to my preface of the present volume. The contrast between the hands is clearly visible.

19 So far the basic data of the manuscript and its text are unknown. Philological, palaeographical and codicological surveys have not been made. The manuscript is the sub- 
impression, but the cross-shaped ornament on the boards makes Islamic manufacture improbable. The usual Medinan double image, which is part of the vulgate text, is on f. 21b-22a. I inspected it by autopsy and photographed it on May 22, 2019, in the stacks of the Museum (my field notes FN 132, ff. 8487 , and my photographic survey). The date in the colophon, 1035/1625-1626, is written partly in ghubār numerals and partly in text. The copyist could be a relative (father?) of the person who also copied ms Dublin, Chester Beatty Library 4223 (dated 1048/1638-1639). Other al-Riyāhī manuscripts of the Dalä'il al-Khayrāt are Ms Paris BnF Arabe 1184 (undated) and Ms Cambridge, University Library Dd. 6. 22 (undated). The al-Riyāhī workshop not surprisingly also produced Qur'ān manuscripts. ${ }^{20}$ Teamwork is evident in all its products. None of the manuscripts known to come from this workshop has an explicit indication of a Tunisian origin.

\subsection{Dated $1048(1638-1639)$}

Ms Dublin, Chester Beatty Library 4223. Arberry, Handlist, vol. 5, p. 70. ${ }^{21}$ Abid, Daläil, vol. II, pp. 17-21, mentions that the ornamental addition in the manuscript contains the genealogy of the Prophet Muhammad, apparently with the names of al-Ashara al-Mubashshara, the sandal of the Prophet (ff. $2 \mathrm{~b}-3 \mathrm{a}$ ), and topographical views of the mosques of Mecca and Medina on $\mathrm{ff} .3 \mathrm{~b}-4 \mathrm{a}^{22}$ Abid, following Arberry, mentions the copyist as Muhammad b. Muhammad b. Aḥmad b. 'Abd al-Raḥmān al-Riyāhī, according to the colophon on f. 93a. He could be family of the 'copyist' of MS New York, Metropolitan Museum, 2017.301 and of Ms Paris BnF Arabe 1184. Abid has published images of the double car-

ject of the contributions by Deniz Beyazit and Yana van Dyke to the present volume. See for images https://www.metmuseum.org/art/collection/search/752280 (accessed on 27 April 2021). It was purchased for GBP 15,00o from Christie's London, Auction 27 April 2017, No. 99. https://www.christies.com/lot/lot-muhammad-bin-sulayman-al-jazuli-d1465 -ad-dalail-6o68o29/?from=salesummary\&intObjectID=6o68o29\&lid=1\&ldp_breadcrum $\mathrm{b}=$ back (accessed on 9 May 2021).

20 MS Paris, BnF Arabe 7253 (dated 10 Muḥarram 1044 (1634)). https://gallica.bnfffr/ark:/ 12148/btvib8427177p/f2.item.r=Arabe-7253\#; Ms Leipzig, University Library Vollers 65 (undated, part 4 of a 4-volume set) https://www.islamic-manuscripts.net/receive/IslamHSBo ok_islamhs_oooo2405

21 Arthur J. Arberry, The Chester Beatty Library. A Handlist of the Arabic Manuscripts. Volume v. MSs. 4001-450o. Dublin: Hodges, Figgis \& Co., 1962.

22 The Mecca-Medina double image is illustrated in Simon O'Meara, The Ka'ba Orientations. Readings in Islam's Ancient House. Edinburgh: Edinburgh University Press, 2020, p. 122, illustration 5.5 . The image of the sandal in this manuscript on ff. $2 \mathrm{~b}-3 \mathrm{a}$ is reproduced in Hiba Abid, 'Material Images', p. 343. 
pet page (ff. $4 \mathrm{~b}-5 \mathrm{a})$ and the beginning of the text (ff. $5 \mathrm{~b}-6 \mathrm{a}) .{ }^{23}$ Beyazit, in the present volume, reproduces several pages, all from the ornamental addition in this manuscript (ff. $1 \mathrm{~b}-5 \mathrm{~b})$.

\subsection{Dated 1057/1647}

Ms Rabat, Hasaniyya 123o1. Abid, Dalä̉il, vol. II, pp. 21-24, mentions two elements of the ornamental addition in the manuscript: the genealogy of the Prophet Muhammad and the topographic views of Mecca and Medina. Abid does not mention the sandal of the Prophet in relation to this manuscript, nor, it would seem, the list of the Prophet's expeditions. The double Medinan image in this manuscript is reproduced in Abid, 'Material Images', p. 337; Abid has published images of the genealogy of the Prophet with the lives of al-Ashara al-Mubashshara (ff. $3 \mathrm{~b}-4 \mathrm{a}$ ), the images of Mecca and Medina (ff. gb-10a). Abid also reproduced the Medinan double image, which is not part of the ornamental addition (ff. 28b-29a). ${ }^{24}$ Beyazit does not mention this manuscript.

\subsection{Dated 1655}

Ms Paris, Musée Quai Branly 74.1962.o. Said to date from 1066/1655-1656 and to have been copied in Algiers, as van Koningsveld mentions. ${ }^{25}$ From the images that the Museum has placed on the internet one gets the impression that only loose unnumbered leaves are preserved (https://photo.rmn.fr/CS.aspx?VP3= SearchResult\&VBID $=2$ CMFCI2KoFJ_o\&SMLS $=1 \& R W=1872 \& R H=969$ ). The ornamental addition shows the following elements: the Mecca-Medina double image, the labyrinthic image of the pedigree of the Prophet Muhammad with the names of al-Ashara al-Mubashshara, but no information about the sandal nor about the expeditions. Of the Daläil al-Khayrät proper the Medinan double-image is shown.

\subsection{Dated 1695}

Ms London, British Library, unspecified. A manuscript that as ornamental addition at least seems to feature images of Mecca and Medina, and of the sandal of the Prophet. No further information available. ${ }^{26}$

23 Abid, 'Birth', fig. 9.

24 Abid, 'Birth', fig. 6.

25 Koningsveld, 'Puriteinen'.

26 Thus mentioned by van Koningsveld, 'Puriteinen'. The catalogues by Cureton (1846), pp. $75^{-78}$, and Rieu (1894), p. 165 , do not refer to a manuscript that would match van Koningsveld's reference. 


\subsection{Dated Dhü al-Qa'da 1110 (1699)}

ms Dublin, Chester Beatty Library 4240. Arberry, Handlist, vol. 5, p. 75. Abid, Daläil, vol. II, pp. 43-47, mentions that the ornamental addition to the manuscript contains the genealogy of the Prophet Muhammad, possibly with al'Ashara al-Mubashshara, topographic views of the mosques of Mecca and Medina (ff. 15b-16a), and the sandal of the Prophet (ff. 17b-18a). No word about the list of expeditions, but it could be there mevertheless. Inside the text is the Medinan double image.

\subsection{Dated 17 Shawwäl 1116 (1705)}

Ms Paris, BnF 6983 (Réserve 1517), Abid, Dalä'il, vol. II, pp. 47-51. See my detailed description, below (with figures 4-7). ${ }^{27}$ The ornamental addition shows half a carpet page (f. $2 \mathrm{~b}$ ), the genealogy of the Prophet with al-Ashara al-Mubashshara (ff. $4 \mathrm{~b}-12 \mathrm{~b}$ ), the twenty-one expeditions of the Prophet Muhammad (f. 14a), topographical views of Mecca (f. 14b), and of Medina (f. 16a), the sandal (ff. 16b-17a), and double-page illumination (ff. 17b, 19a). The text of the Daläil begins on $\mathrm{f}$. 19b. Inside the text is the Medinan double image (ff. $36 \mathrm{~b}, 38 \mathrm{a}$ ). Full facsimile: https://gallica.bnf.fr/ark:/12148/btvib84061483.r=Arabe-6983?rk $=21459 ; 2$

\subsection{Copied before 1 Ğumādā I $1213(1798)$}

MS Berlin, Staatsbibliothek, Or. oct. 240, dating from before 1213/1798. ${ }^{28}$ Abid, Daläil, vol. II, pp. 192-196. A convolute volume. All text in the volume is preceded by a waqfiyya, dated 1213/1798. The ornamental addition consists of the following elements: genealogy of the Prophet Muhammad with al-Ashara alMubashshara (ff. $1 \mathrm{~b}-4 \mathrm{a}$ ), the expeditions of the Prophet Muhammad (ff. $4 \mathrm{~b}-$ $5^{a}$ ), the Mecca-Medina double illustration (ff. $5 \mathrm{~b}-6 \mathrm{a}$ ). No mention of the sandal. The text of the Dalä'il al-Khayrät is on ff. $6 \mathrm{~b}-87 \mathrm{~b}$. The Medinan double illustration is in the text, on ff. $17 \mathrm{~b}-18 \mathrm{a}$.

The Mecca-Medina double image in this manuscript is very similar to that in M s Toronto, Aga Khan Museum AKM 535, ff. 16b-17a. See my detailed description, below, of the Berlin manuscript (with figures $8-11) \cdot{ }^{29}$ Full facsimile:

27 The volume is digitally on view: https://gallica.bnf.fr/ark:/12148/btvıb84061483.r=arabe $\% 206983$ ? rk=21459;2 (accessed on June 15, 2020).

28 A waqfiyya for the deposition of the manuscript in al-huğra al-nabawiyya (in Medina), which is dated 1 Ğumādā I 1213 (1798), can be seen on f. 1a of the Berlin manuscript. The manuscript itself must therefore be at least somewhat older.

29 The link that Abid gives at the end of her description (http://goo.gl/G2qkQx) does not refer to this manuscript but to Ms Berlin, Staatsbibliothek, Petermann II Nachtrag 12. The 
https://digital.staatsbibliothek-berlin.de/werkansicht?PPN=PPN793014964\&P HYSID=PHYS_OoO1\&DMDID=

\subsection{Dated 14 Ramaụān 1244 (1829)}

Ms Rabat, Bibliothèque nationale 399. Abid, Daläil, vol. II, pp. 86-89. ${ }^{30}$ Copy by the calligrapher Muhammad b. al-Qāsim al-Qundūsī (d. 1278/1862). The ornamental addition contains the genealogy and the image of the sandals.

\subsection{Undated, Possibly 16th Century}

Ms Paris, BnF Arabe 1180. The estimated dating is to the 16th century (De Slane's catalogue), and the acquisition history of the manuscripts in French collections may shed more light on an ante quem dating. Only one leaf (f. 1 ) in this volume seems to belong to the ornamental addition. It is very similar to Ms New York, Metropolitan Museum, 2017.301, f. 15. The rest of the volume may have a different origin, but not necessarily. Many notes refer to al-Rașșāc (ff. 6b, 15a, 16a, 25a, 44b, 46a, 49b, 5oa, 55a, 56a). ${ }^{31}$ His Tunisian origin may indicate that the manuscript originates from Tunisia.

Full facsimile: https://gallica.bnf.fr/ark:/12148/btvib110oo669p/f2.item.r=ar abe\%20118o.zoom

\subsection{Undated, Estimated Mid-17th Century}

MS Vienna, Österreichische Nationalbibliothek Mixt. 1876. There exists a facsimile edition of this luxury manuscript. ${ }^{32}$ It is a convolute volume with 13 different texts distributed over $318 \mathrm{ff}$. , the first text of which is the Daläil alKhayrāt (ff. 21b-10oa). That is preceded by the ornamental addition (ff. 1a-21a). The volume has a carpet double-page at the beginning (ff. $1 \mathrm{~b}, 3 \mathrm{a}$ ) and the end

Mecca-Medina double image in this manuscript is also illustrated in O'Meara, Ka'ba, p.127, No. 5.10.

30 Illustration in Marie-Geneviève Guesdon \& Annie Vernay-Nouri (eds.), L'art du livre arabe. Du manuscrit au livre d'artiste. Paris: Bibliothèque nationale de France, 20o1, p. 68, No. 38. Description by Annie Vernay-Nouri.

31 He is the Tunisian scholar Abū 'Abdallāh Muḥammad b. Abī al-Faḍl Qāsim al-Rașșāc alAnșārī al-Mālikī (d. 894/1489), GAL G II, 246-247, S II, 345. His interest in taṣliya is clear from his book al-Khamsamia Șalāt 'alā al-Nabì. See the edition by Nizār Ḥammādī, alKuwayt: Dār al-Ḍiyā’ lil-Nashr wal-Tawzī', 1433/2012. He was born in Tlemcen. In 831/1428 he arrived at a young age in Tunis. With many others he may have been instrumental in the spread of the Dalä'il al-Khayrāt to the East.

32 Jazūlī, Dalāil al-hairāt und andere Texte: "Anthologie". Vollständige Faksimile-Ausgabe im Originalformat des Codex Vind. Mixt. 1876 aus dem Besitz der Österreichischen Nationalbibliothek. Ed. Tarif al Samman. Graz: Akademische Druck und Verlagsanstalt, 1987. 2 vols (Faksimile, Kommentar with illustrations). 
(ff. 316b, 318a). The ornamental addition contains Qurānic calligraphies (ff. 3b, $5 \mathrm{a})$, the genealogy of the Prophet with the names of al-Ashara al-Mubashshara (ff. $7 \mathrm{~b}-13 \mathrm{~b}$ ), the sandal of the Prophet Muhammad (ff. 15b, 17a), the expeditions of the Prophet Muhammad (ff. 17b, 19a), the Mecca-Medina double image (ff. 19b, 21a). On f. 21b begins the text of the Daläil al-Khayrāt which ends on f. 110a. The text of the Daläil al-Khayrät seems to be incomplete in that it lacks the section on al-Rawda al-Mubāraka with the double Medinan illustration.

\subsection{Undated, Estimated 12/18th Century (Arberry), or 13/19th Century (Abid)}

Ms Dublin, Chester Beatty Library 5459. Arberry, Handlist, vol. 7 (1964), p. $1544^{33}$ Abid, Daläil, vol. II, pp. 200-203, mentions that the ornamental addition in the manuscript contains the genealogy of the Prophet Muhammad, possibly with al-Ashara al-Mubashshara, the sandal of the Prophet, and topographic views of the mosques of Mecca and Medina. No mentions of the expeditions.

\subsection{Undated, Said To Be from the 12/18th Century}

A manuscript in P.S. van Koningsveld's private collection, containing at least images of the sandal of the Prophet and the Meccan and Medinan sanctuaries. The Mecca-Medina double page with the sanctuaries appears to be an unauthentic collage. ${ }^{34}$

\subsection{Undated, without Estimate}

MS Berlin, Staatsbibliothek, Petermann II Nachtrag 12. The ornamental addition in this manuscripts consists of the following elements: genealogy of the Prophet Muhammad with mention of al-Ashara al-Mubashshara (ff. 1b-2a) and two images of the sandal of the Prophet Muhammad (ff. $4 b-5 a, 5 b-6 a$ ). No mention of the expeditions, nor the Mecca-Medina double illustration. The text of the Daläil al-Khayrāt (ff. 8b-133a) has the Șifat al-Rawḍal-Mubāraka (ff. 25a-29a), which shows the Medinan double illustration (ff. 26b-27a). Full facsimile: http://goo.gl/G2qkQx.

33 Arthur J. Arberry, The Chester Beatty Library. A Handlist of the Arabic Manuscripts. Volume vir. MSs. 5001-550o. Dublin: Hodges, Figgis \& Co., 1964.

34 Illustrations in van Koningsveld, 'Puriteinen'. The sandal image of the same manuscript is shown in P.S. van Koningsveld, The Tomb of the Prophet. Attitudes and Discussions around a Major Religious Symbol in Islam. Leiden: Leiden University, 2007. [with Arabic translation by Mohammed Ghaly, and a selective autobibliography of the author], p. 18, figure 6. 


\subsection{Undated, Estimated 13/19th Century}

Ms Fes, Qarawiyyīn $3226 .{ }^{35}$ Abid, Daläil, vol. II, pp. 206-209, mentions that the ornamental addition in the manuscript contains the genealogy of the Prophet Muhammad, possibly with the Ashara, the sandals of the Prophet, and topographic views of Mecca and Medina. Abid does not mention the expeditions.

\subsection{Undated, Estimated 13/19th Century}

Ms Rabat, Bibliothèque nationale G 356. Acephalous copy of the Daläil alKhayrāt, preceded by the ornamental addition, in a convolute volume comprising 44 texts in all, whereas at the end there must have been another 11 texts that are now lost. The ornamental addition contains the genealogy (12 pp.) and the list of expeditions (1 p.). There exists a facsimile edition of this manuscript. ${ }^{36}$ Also see Abid, Dalä̉il, vol. II, pp. 198-200.

\subsection{Undated, Estimated 13/19th Century}

Ms Kuala Lumpur, Islamic Art Museum Malaysia (IAMM) 2011.1.23, a Maghribi manuscript. See Nurul Iman Rusli, Heba Nayel Barakat and Amira Salleh (eds.), Dalail al-Khayrat. Prayer Manuscripts from the 16th-19th Centuries. Kuala Lumpur: Islamic Art Museum Malaysia, 2016, 36-39 (Catalogue 5). The ornamental addition consists of illustrations of the sandal, the topographic views of Mecca and Medina (same style as Ms Berlin, Staatsbibliothek, Or. oct. 240), the Prophet's genealogy, and the Prophet's 21 ghazawāt.

\subsection{Undated, Estimated 13/19th Century}

Ms Toronto, Aga Khan Museum, AKM 535, seems to belong to the group of luxury Maghribì manuscripts of the Daläil al-Khayrāt with the ornamental addition. ${ }^{37}$ The Mecca-Medina double image (ff. $16 \mathrm{~b}-17 \mathrm{a}$ ) is very similar to those in

35 Abid, Daläil, vol. I, pp. 259, 266, 267, 272 also refers to this manuscript as Ms Rabat, Hasaniyya 3226 , but this seems to be a mix-up.

36 Ahmed Toufiq \& M.-G. Guesdon (eds.), Dalāill al-Khayrāt wā Shawāriq al-Anwār fì așȘalāt 'alā an-Nabī al-Mukhtār et autres textes panégyriques et d'invocation. Facsimilé du manuscrit $n^{\circ} \mathrm{G} 356$ de la Bibliothèque nationale du Royaume du Maroc (ancienne Bibliothèque Générale et Archives). Introduction et commentaire, Rabat, Royaume du Maroc, Ministère des Habous et des Affaires Islamiques, 2003.

37 Margaret S. Graves, Benoît Junod, Gérard Friedli, Aga Khan Trust for Culture, Aga Khan Museum, Architecture in Islamic Arts: Treasures of the Aga Khan Museum. Geneva: Aga Khan Trust for Culture, 2011 pp. 46-47, cat. No. 3. See also the digital collection catalogue entry of the Aga Khan Museum by Deniz Beyazit: https://www.agakhanmuseum.org/ collection/artifact/dala-il-al-khayrat-prayer-book-akm535 (accessed on 25 April 2021), where the Mecca/Medina double image is reproduced. 
the other manuscripts in this subgroup, especially to that in Ms Berlin, Staatsbibliothek Or. oct. 240 of before 1213/1798.

\subsection{Undated, Estimated 13/19th Century}

Ms Tunis, Bibliothèque nationale 363o. Abid, Daläil, vol. II, pp. 174-177, who describes the exceptional set of illustrations in this manuscript: the Rawda is illustrated eight times (ff. $24 a-28 b, 38 b-39 a, 41 b-43 a)$. The elements that are usually part of the ornamental addition are: genealogy (ff. 29a-35a), the sandals (ff. 36b-37a, 37b-38a), the Mecca-Medina double image (ff. 4ob-41a).

Below, I describe two manuscripts with the additional ornament in greater detail. I selected them for pragmatical reasons only, being easily available in an electronic format.

\subsection{MS Paris, Bibliothèque nationale de France, Arabe 6983 (Réserve $1517)^{38}$}

This is a luxury copy from the Maghreb of the Daläil al-Khayrāt (ff. 19b-135a), and shows the ornamental addition that I have just defined. All features of the luxury copies can be seen (ff. $2 \mathrm{~b}-19 \mathrm{a}$ ). It measures $22 \times 16.5 \mathrm{~cm}$. The volume was commissioned by al-Qā'id Abū Zayd 'Abd al-Raḥmān b. Abī 'Abdallāh Muḥammad b. al-Ashqar. It is dated Thursday, 17 Shawwāl 1116 (1705). The lavishly executed calligraphy and illumination is similar to that of a Qurān manuscript. The tahlil is coloured, usually in gold, but also red and blue, and includes the name of Muhammad and references to him.

ff. 1a-2a. Preliminaries from the owners, not the copyist:

f. 1a. Fä̀ida against the evil eye, written in a common Maghribı̄ hand. F. 1 b. Blank.

f. 2a. Readers' notes of familial nature, in three different common Maghribi

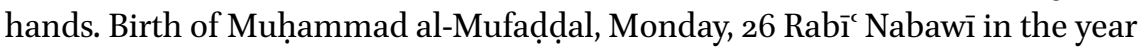

38 See Guesdon \& Vernay-Nouri, L'art du livre arabe. No. 68 (pp. 100-101, with the description by Marie-Geneviève Guesdon). The manuscript entered the BnF in 1975. It was part of the collection of Maréchal Hubert Lyautey (1854-1934). The description that follows here is based on my autopsy of the volume in March 2005 and on the presentation in Gallica https://gallica.bnf.fr/ark:/12148/btvıb84061483.r=Arabe-6983?rk=21459;2. A detailed description is also in Abid, Daläil, vol. II, pp. 47-51, her siglum D2o. 
19 (=? 1119/1707); birth of Muhammad b. 'Abd al-Raḥmān b. al-Ashqar, on Monday, 19 Ğumādā I 1123 (1711), while the moon was in Pisces and Leo with Leo as ascendant. ${ }^{39}$ The third note contains an instruction on the authority of Sīdi Muhammad al-'Ayyāsh about how to perform the dhikr Allāh.

Thereafter, there is only work of the copyist, miniaturist, and illuminator, whose names are not given.

(1) ff. 2b-19a. The ornamental addition shows the following features:

f. 2 b. Single carpet page, filled with a geometrical illumination based on the division of the circle into twelve (centre piece) and sixteen (corner pieces). The illuminated title-page of the genealogy (f. 4a) may be the counterpart to this page. Ff. $3 \mathrm{a}-\mathrm{b}$ are original protective leaves between $\mathrm{ff} .2 \mathrm{~b}$ and $4 \mathrm{a}$, showing some offset of their opposite pages.

ff. 4a-12b. The pedigree of the Prophet Muhammad. The illuminated pages are separated from each another by protective leaves and give the following genealogy, written in Maghribi thuluth script in gold ink with black outline. The text is continuous, the pages being interconnected with the word bin, 'son of', written in an elongated style:

$$
\begin{aligned}
& \text { شجرة خير | الانام الى ادم | عليه السلام || محمد | صلى الله عليه وسلم | ابن عبدالله بـ || - سن عبد }
\end{aligned}
$$

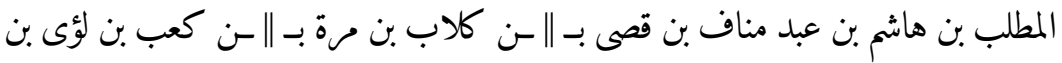

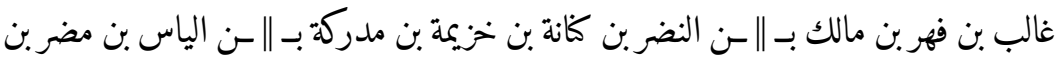

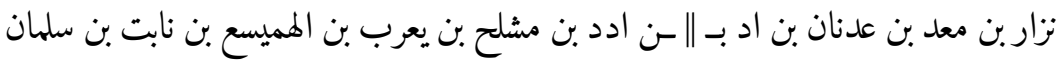

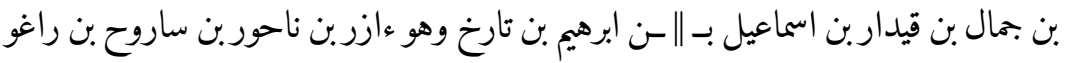

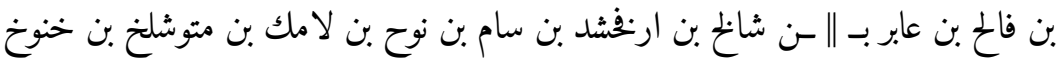

$$
\begin{aligned}
& \text { وهو ادريس فيما يزعمون بن يرد بن ههليل بن قيس بن يانش بن شيث بن بن ءادم وحوا عليهما }
\end{aligned}
$$

On the last page (f. 12b), the genealogy takes the form of a centripetal spiral, or maybe a labyrinth.

On ff. 6a, 6b and 8a the names of the al-Ashara al-Mubashshara have been written in Maghribi thuluth script in gold ink, inside illuminated circles in the

39 Written by or on behalf of the person who commissioned the volume and whose name is given in the calligraphic inscription on f. 133a, preceding the colophon. It shows that the manuscript remained in the personal possession of that person. 
corners of the page. Added to each of these is a further genealogy in minute Maghribī script in red ink, given hereunder between square brackets:

$$
\begin{aligned}
& \text { على رضى الله عنه [بن ابى طالب] - عثمان رضى الله عنه [بن عفان بن ابى العاصى بن اميّة }
\end{aligned}
$$

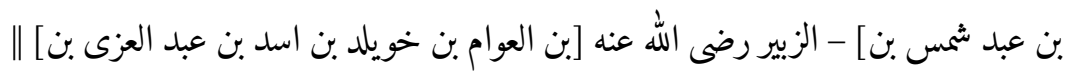

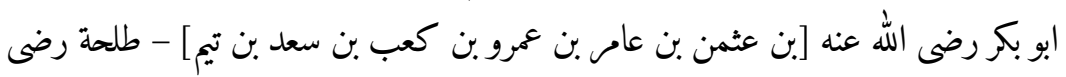

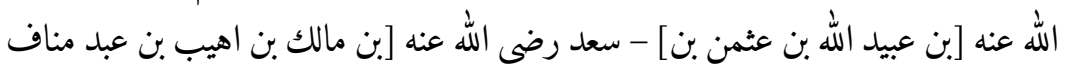

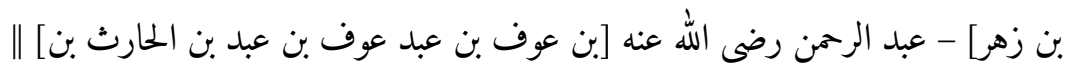

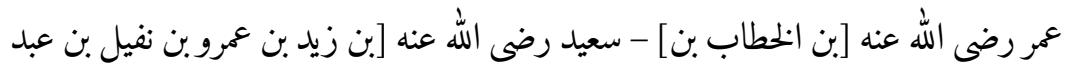

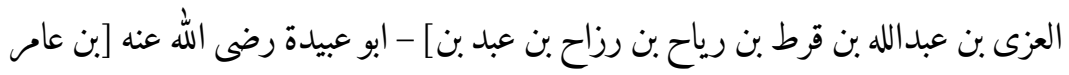

$$
\begin{aligned}
& \text { || بن عبد الله }
\end{aligned}
$$

On f. 14a mention is made of the twenty-one expeditions of the Prophet Muhammad:

$$
\begin{aligned}
& \text { غزوات النبى صلى الله عليه وسلم | وهى احدى وعشرين غزوة غزوة ودان | غزوة بنى }
\end{aligned}
$$

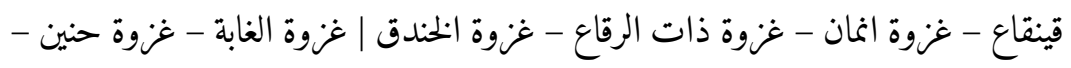

$$
\begin{aligned}
& \text { غزوة عين قريش - غزوة السويق |غزوة احد - غزوة دومة الجندل - غزوة بنى قريظة - } \\
& \text { غزوة خسر | غزوة الطايف - غزوة بدر - غزوة بنى سليم - غزوة بنى النضير | غزوة بنى بنى }
\end{aligned}
$$

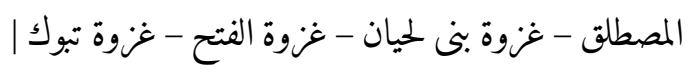

On f. $14 \mathrm{~b}$ is a topographical drawing of the Great Mosque in Mecca (figure 4).

The text of the legends is written in Maghribi thuluth script in gold ink with black outline, against backgrounds filled with floral motifs. Above and below the illustration of the mosque are horizontal bands with text that reads (a Ta'wìdh followed by part of Qurān 5:97):

$$
\text { اعوذ بالله من الشيطان الرجيم جعل الله | الكعبة البيت الحرام قياما للناس والشهر الحرام | }
$$

With the exception of the word ma'dhana, minaret, the legends are all presented as part of the illuminated drawing, written in Maghribi thuluth script in gold ink with black outline. The centre piece, the Kaba, is damaged, possibly as a result of the oxidation of copper in coloured ink, but maybe also from frequent touching. 


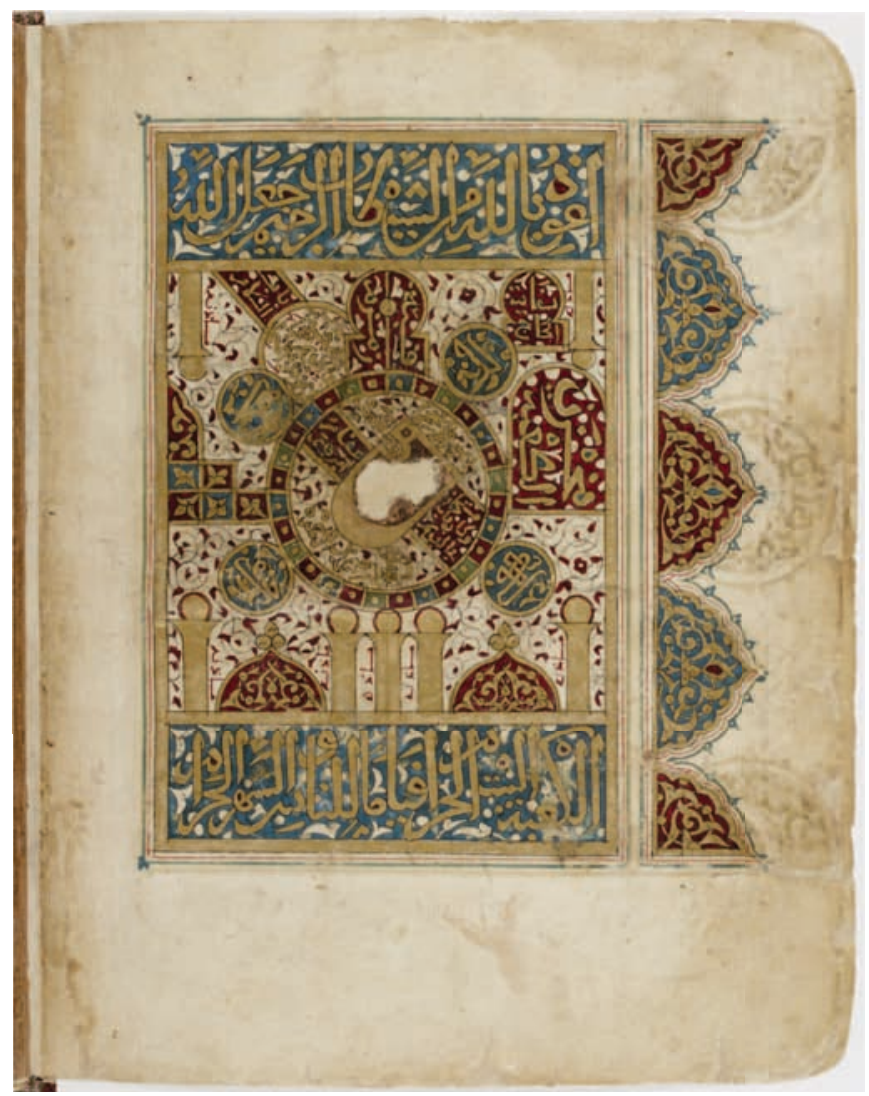

FIgURE 4 The Mecca image as it occurs in the ornamental addition to a luxury manuscript, preceding the text of Dalā'il al-Khayrāt, from the Maghrib, dated 1116/1705 MS PARIS, BNF, ARABE 6983, F. 14B

The inner court of the mosque is an approximate square. Inside the court, details are described with legends, hereunder quoted in italics. The orientation is with the East on top, the West at the bottom, the South to the right, and the North to the left. There are no legends for the directions of the compass. All seven minarets are depicted and have the legend ma'dhana (two against the East wall, five against the West wall). A central circle contains the Ka'ba. Its entrance is in the North-East wall, called $B \bar{a} b a l-K a c b a$. To the North-East is the Maqām Ibrāhim, to the South-East is the black stone, al-Hağar al-Aswad, indicated as a black dot inside the structure of the Kaba. To the South-West is a secluded area, 'Mustaha $\bar{a} z$, which in former times was a gate'. To the West is a section, the legend of which cannot longer be read. To the North-West is the Miza a b al-Rahma. On the circle surrounding the Ka'ba are four blue circles 
with white floral motifs that carry the names of the four Law schools written in gold: Shäfī (North-East); Hanbalī (South-East); Mãlikì (South-West); and Hanafi (North-West). Pointing eastward is the Qubbat Zamzam. Slightly to the South of that is a location called siqāyat al-hāḡğ, 'water supply for the pilgrims'. Between Zamzam and Shäfi $i$ is a golden enclosure with the legend Bāb Banī Shayba fil-qadìm 'umila an yazdāda fil-masğid, 'the Gate of the Banū Shayba in early times built as an extension to the mosque'. The Banū Shayba are the family of key keepers of the Ka ${ }^{a}$ ba. From the Bāb BanīShayba, the path goes to the $B \bar{a} b$ al-Saläm, towards the North-East. In the West wall are two drawings for gates, without legends. In the far South is a structure called makhzan al-Ka'ba, 'the treasury of the Kaba'. And to the far North is a pulpit with two steps, without a legend.

F. 16a features a topographical drawing of the Prophet's mosque in Medina (figure 5).

The centre piece is damaged, possibly as a result of the oxidation of copper in coloured ink. Most legends are written in Maghribi thuluth and also neo-Kufic script in gold ink with black outline, against backgrounds filled with floral motifs. Above and below the illustration of the mosque are horizontal bands with text that reads the sequel of the Qurānic verse of the previous page (Qur'ān 5:97):

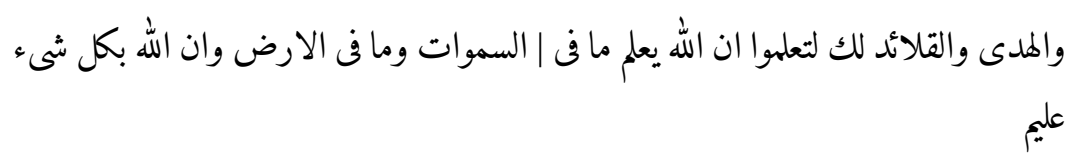

The orientation is $90^{\circ}$ different from that in the Meccan image, with South on top, North at the bottom, West to the right, and East to the left. Only two directions are indicated with a legend: the eastern wall with al-mashriq; the western wall with al-maghrib. The inner court of the mosque is an approximate square. Inside the court, details are described with legends. In the centre of the court are two partly overlapping rectangles of different dimensions. The eastern rectangle is an enclosure that contains the burial chamber, here shown as a niche

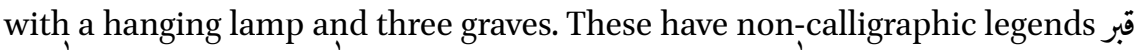
the grave of the Chosen One, may God bless him and grant him pease; the grave of Abū Bakr the honest, may God be pleased with him; the grave of 'Umar, may God be pleased with him'. A triangular space North of the chamber (reading uncertain): yuqāl min hunā ilā hăàit al-ḥuğra al-nabawiyya ... '...(?) from here to the wall of the burial chamber of the Prophet'. Inside the western rectangle, near the South-West corner of the burial chamber is a small circle in gold. The leg- 


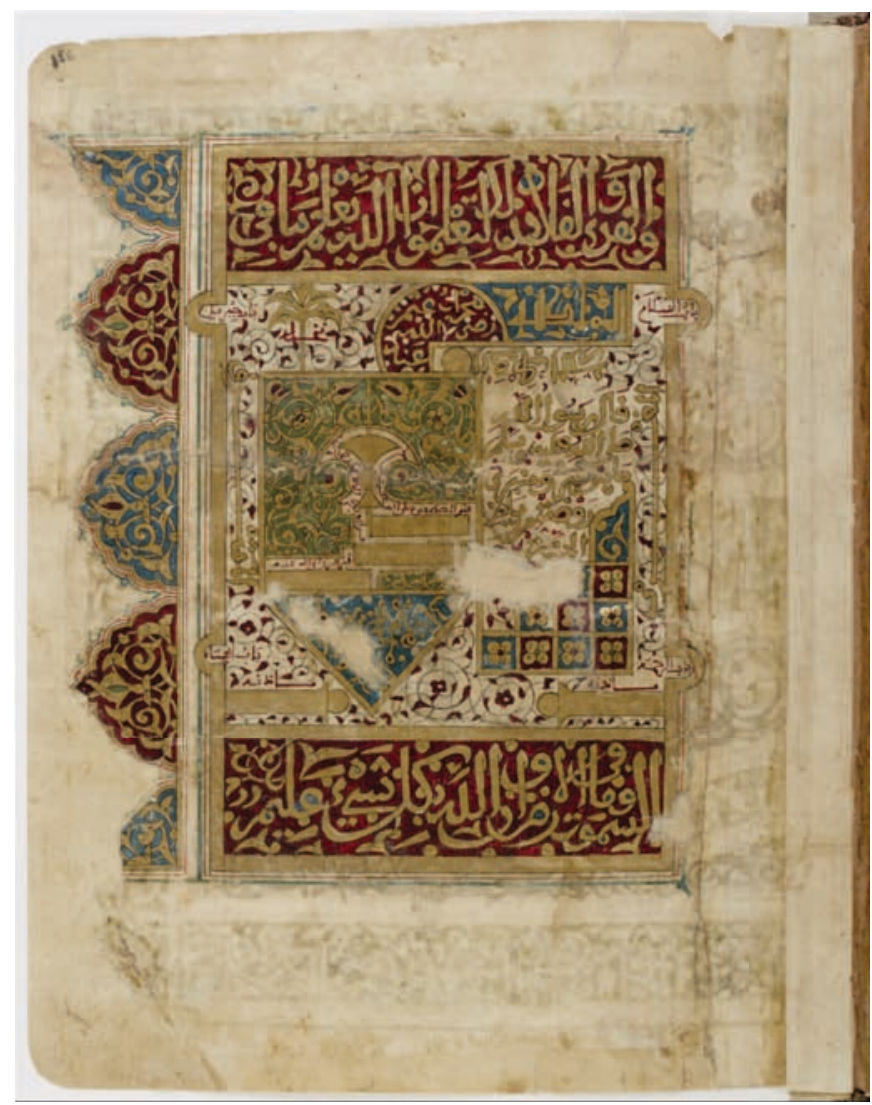

FIGURE 5 The Medina image as it occurs in the ornamental addition to a luxury manuscript, preceding the text of Daläil al-Khayrät, from the Maghrib, dated 1116/1705 MS PARIS, BNF, ARABE 6983, F. 16A

end indicates that this is al-kawkab al-durrī, 'the Brilliant Star'. ${ }^{40}$ The rest of the western rectangle is filled with the text of the mä bayna Tradition:

40 The 'Brilliant Star' is usually an epithet associated with the Prophet Muhammad. In this context, the gold circular shape in the wall of the burial chamber is a set of jewellery, set in a circular setting of gold and silver. Muhammad Labīb al-Batanūnī, al-Rị̣la

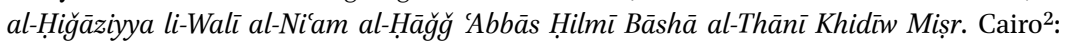
Mațba'at al-Ğamāliyya, 1329 (1911), p. 248, mentions it: 'Opposite the noble face [of the Prophet Muhammad] on the wall of the enclosure is a brilliant as large as a small dove's egg. It is held in a setting of gold. The intrinsic value of it is estimated to be eight hundred thousand Egyptian pound, but because of the noble place where it is kept, its value is considered to be eight times as high. It is called al-kawkab al-durrī because of its strong 


$$
\text { قال رسول الله | صلى الله عليه وسلم | ما بين قبرى ومنبرى| روضة من رياض | الجنة | }
$$

The western rectangle also contains the pulpit, minbar, seen from the side, with three steps. To the far South, in the centre, is the mihrāa 'Uthmān radiya Allāh 'anhu, the prayer niche ascribed to the third caliph, 'Uthmān b. 'Affān. Within the frame in the North-East and the North-West wall are two minarets, ma'dhana. Gates are indicated in the upper and lower western and eastern corners: Bāb Ğibrīl (South-East); Bāb al-Salām (South-West); Bāb al-Rahma (North-West); Bāb al-Nis $\bar{a}^{\prime}$ (North-East). A palm is growing South of the enclosure of the burial chamber, nakhla. It indicates Fāțima's garden. ${ }^{41}$

On ff. $16 \mathrm{~b}-17 \mathrm{a}$ is an illustration of the sandal of the Prophet Muhammad. Its outlines and borders feature calligraphic texts in Maghribi thuluth script written in gold ink with black outline. These are all poetry by al-Maqqarī (d. 1041/1631), who is well-known for his work about the Prophet's sandal. ${ }^{42}$ In the outer border are six lines of his poetry: ${ }^{43}$

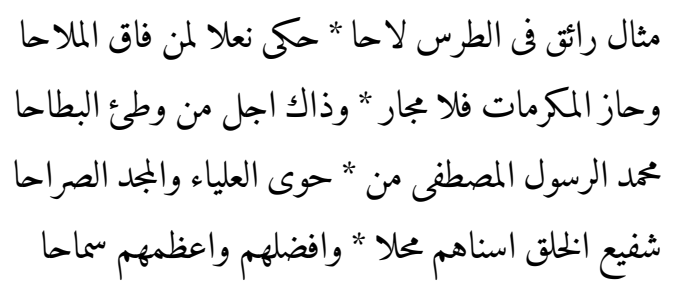

sparkling properties and its great splendour and beauty. It is fixed on a board of gold, and around it are set two hundred and twenty-seven large pieces of precious stones. This 'Star' was given to the chamber by the Ottoman Sulțān Ahmad I [r. 1012-1026/16o3-1617] in the beginning of the 11th (17th) century. Behind it hangs a hand made of gold in which precious stones are set. In its centre there is a diamond that is smaller than al-kawkab al-durri, which was donated by Sulțān Murād IV [r. 1032-1049/1623-1640] in the year 1047 (16371638 )'. On older images and in previously made descriptions of the maqșūra, we sometimes see 'the Nail', al-mismār, made of silver, mentioned at this spot. It seems that al-kawkab al-durrī replaced it.

41 Bustān al-Sayyida Fāțima, as shown in a map by al-Batanūnī, al-Rihlala, between pp. 243244 .

42 Checked against two different editions: al-Maqqarī, Wașf Nicāl al-Nabī al-Musammā biFath al-Muta'āl fì Madh al-Nicâl, edited by 'Alī 'Abd al-Wahhāb \& 'Abd al-Mun'im Farağ Darwīsh. Cairo: Dār al-Qāḍī Tyāụ lil-Turāth, n.d.; al-Maqqarī, Fatḥ al-Muta'āl fì Madḥ alNicăl, edited by Aḥmad Farīd al-Mazīdī. Beirut: Dār al-Kutub al-'Ilmiyya, n.d. Al-Maqqarī’s Was $f$ is often quoted in this context. See on the sandals of the Prophet also Abid, Dala'il, vol. 1, pp. 275-277, who provides partial transcriptions and translations. 


$$
\begin{aligned}
& \text { فضعه على المحاجر منك والثم * محاسنه فعرف والنفح فاحا } \\
& \text { وصل على مشرفه وسلم * تنل من ذاك في القصد النجاحا }
\end{aligned}
$$

The border of the sandal itself is filled with five lines of poetry by al-Maqqarī:44

$$
\begin{aligned}
& \text { تمثال نعل محمد خير الورى * مرغت خدا ضارعا اتقرب } \\
& \text { باب لتبليغ السعادة موصل * ولكل قصد للنجاح مجرب لمكاب }
\end{aligned}
$$

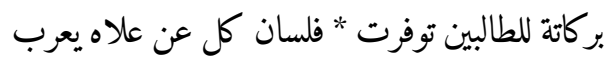

$$
\begin{aligned}
& \text { بالروح افدى نعله فلقد سنت * في القدر والامثال فيها تضرب } \\
& \text { بترابها الغبراء باهت فى العلا * وسما بذلك شرقها والمغرب }
\end{aligned}
$$

The central text inside the sandal consists of two lines of poetry by alMaqqari: ${ }^{45}$

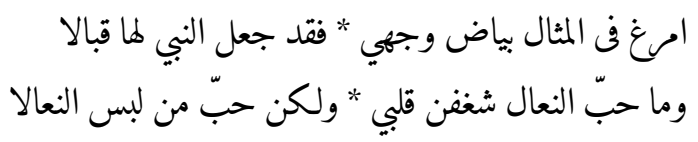

(2) ff. 17b-135a. The text of the Daläil al-Khayrāt by al-Ğazūlī.

ff. 17b, 19a. Both pages feature an identical niche filled with illumination, without legend. In the margin of f. 19a is an owner's note: ${ }^{46}$

$$
\begin{aligned}
& \text { الحمد لله | ملك لله تعلى فى يد عبيد | ربه بن داود بن العربى | بن المعطى بن صالحم وفقه | الله }
\end{aligned}
$$

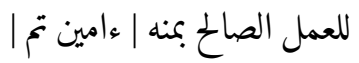

f. 19b. At the beginning of the text of Daläil al-Khayrāt, with the author's name in an illumination:

$$
\begin{aligned}
& \text { بسم الله الرحمن الرحيم | صلى الله على سيدنا محمد وءاله وصحبه وسلم | قال الشيخ الامام | العالم }
\end{aligned}
$$

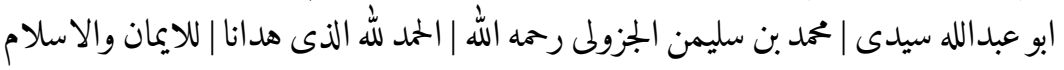

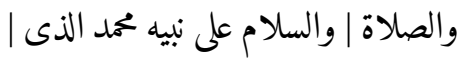

\footnotetext{
44 Ibid., pp. 228-229.

45 Al-Maqqarī, Fatḥal-Mutačal, p. 240, where أمال is used instead of شغفن. Romanization and translation of these two lines by Abid, Daläil, vol. II, p. 49.

46 He is identified by Abid, Dalä il, vol. II, p. 51, as the grandson of the founder of al-Zāwiya al-Nāșiriyya in Tamgrout, but her reading of his name is different from mine.
} 


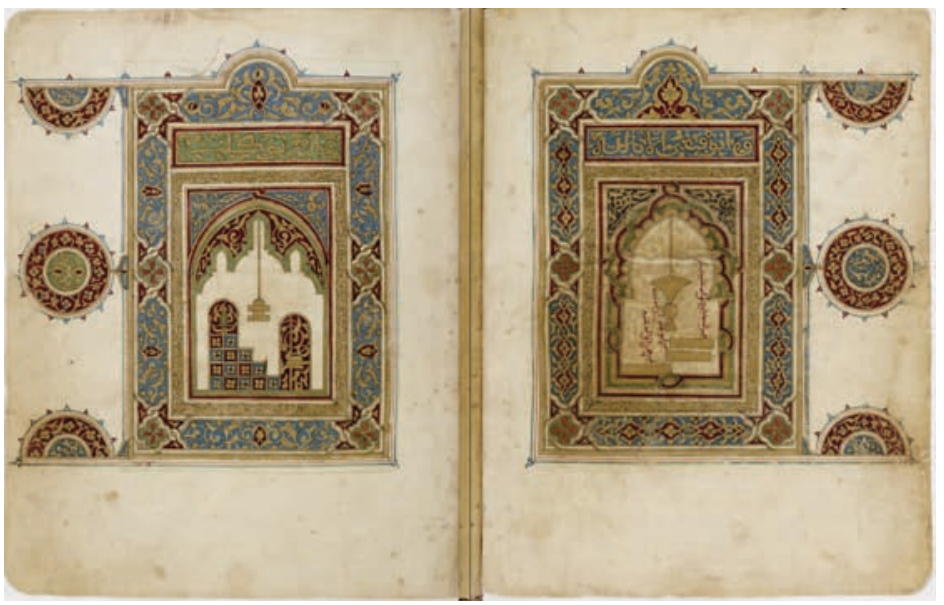

FIGURE 6 The Medinan double image as it occurs in a luxury manuscript of Daläil al-Khayrāt from the Maghrib, dated 1116/1705. MS Paris, BnF, Arabe 6983 (dated 1116/1705), f. $36 \mathrm{~b}$ (burial chamber, right) and f. $38 \mathrm{a}$ (pulpit and prayer niche, left). In the original manuscript the individual images are separated by protecting leaves, which have been omitted here.

f. 36a. Illuminated page with a section title șifat al-rawda al-mubāraka.

ff. $36 \mathrm{~b}, 38 \mathrm{a}$. The Medinan double image (figure 6).

f. $36 \mathrm{~b}$. Illuminated page showing the Medinan burial chamber, here shown as a niche, with a lamp hanging down and the three tombs. Above the image of the niche is a calligraphic band that reads وما توفيقى الا باله : The tombs have legends: Qabr al-Muștafā șallā Allāh 'alayhi wa-sallam; Qabr Abū Bakr radiya Allāh 'anhu; Qabr 'Umar radiya Allāh 'anhu.

f. 38a. Illuminated page showing part of the interior of the Prophet's mosque in Medina, here shown as a niche, with a lamp hanging down, and the minbar (3 steps) and miḩrāb. The latter carries the calligraphic text miḥrāb in neo-Kufic script. Above the image of the niche is a calligraphic band that reads عليه توكلت.

f. $38 \mathrm{~b}$. Description of the burial place of Jesus. ${ }^{47}$

ff. 38b-39a. Anecdote of the dream of 'Â'isha. The first section of tașliya begins at the end of $\mathrm{f}$. $39 \mathrm{a}$.

The text is divided into quarters, thirds, and halves, which are marked by illuminations (ff. 6oa-b, 67b, 81b, 10ob, 107b, 133a). The hizbs are indicated with circular illuminations in the margins.

47 This feature is mentioned as part of the text in most manuscripts of Daläil al-Khayrät. It is not often shown in the miniatures, however. An exception is, for example, Ms München, 


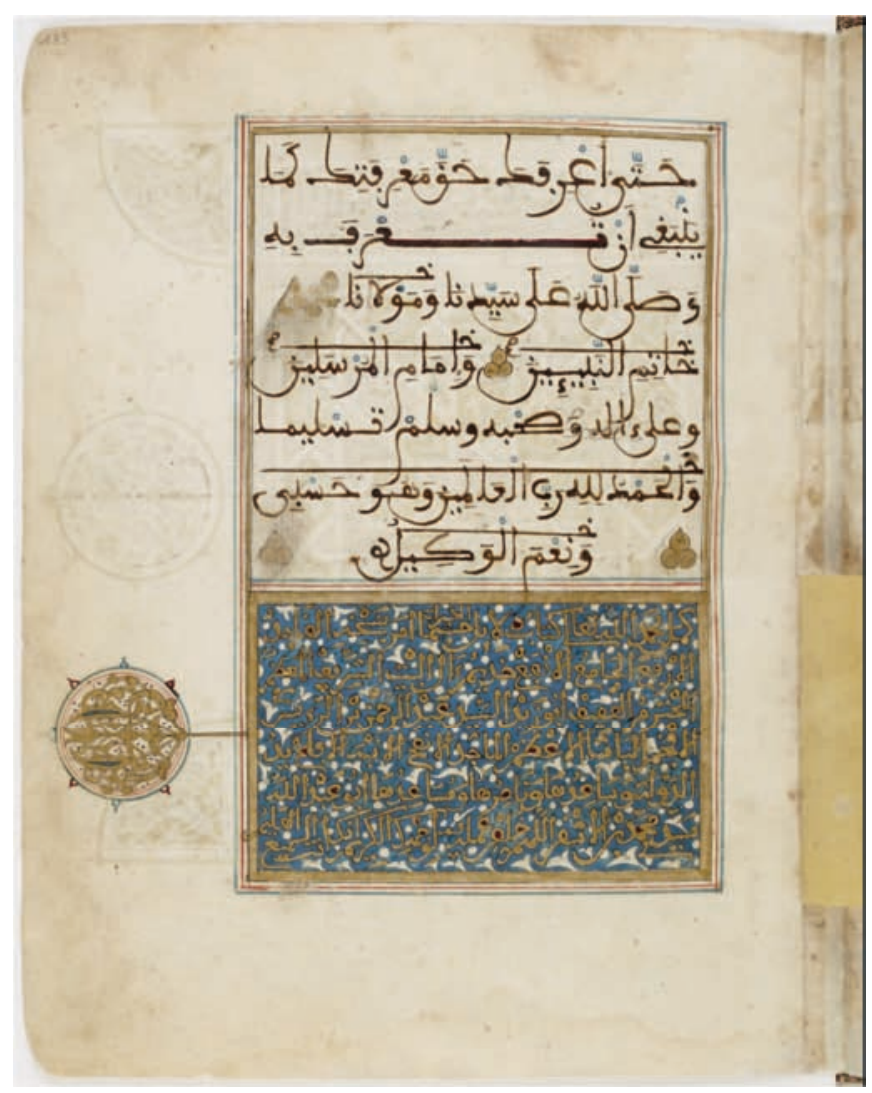

FIGURE 7 The end of the text of Daläil al-Khayrāt by al-Ǧazūlī, followed by the inscription that mentions the person who commissioned the manuscript: al-Qā̉id Abū Zayd 'Abd al-Raḥmān b. Abī 'Abdallāh Muḥammad b. al-Ashqar. Manuscript from the Maghrib MS PARIS, BNF, ARABE 6983 (DATED 1116/1705), F. $133 \mathrm{~A}$

f. 133a. End of the text, followed by an illuminated note, mentioning the personality who commissioned the manuscript: al-Qā̉id Abū Zayd 'Abd alRaḥmān b. Abī 'Abdallāh Muḥammad b. al-Ashqar (figure 7):

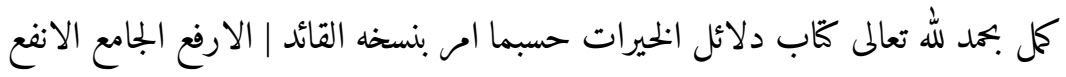

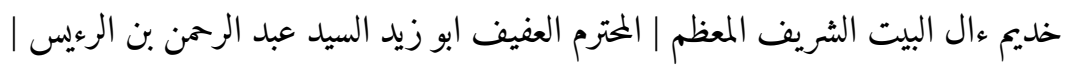

Bayerische Staatsbibliothek, Cod. Arab. 2852, a manuscript from Kashmir dated 1223/1808, in which the enclosure contains a modestly executed Makān 'Tsā 'alayhi al-Saläm. 


$$
\begin{aligned}
& \text { الانفم الباشا الاعظم الماجد الانفح الانبه الافلح يد | الدولة وساعدها وناصرها ومساعدها }
\end{aligned}
$$

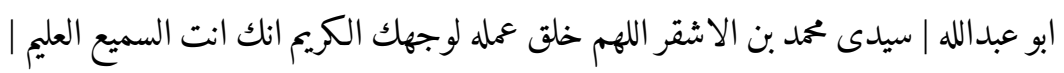

ff. 133b, 135a. Two fully illuminated pages contain the colophon, which gives the date of completion of the volume as Thursday, 17 Shawwāl 1116 (1705):

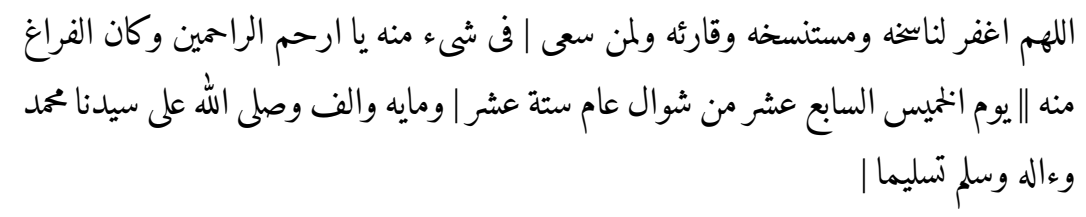

Full-leather Oriental binding with flap with gilded ornamentation. The volume underwent restoration in the library in 1975 under No. 2601.

\subsection{MS Berlin, Staatsbibliothek, Or. oct. 240}

Another example of the lavishly executed copies of Daläil al-Khayrāt is MS Berlin, Staatsbibliothek, Or. oct. $240 .{ }^{48}$ The ornamental addition is on ff. $1 \mathrm{~b}-$ $6 \mathrm{a}$, but there is no image or mention of the sandal. On ff. $6 \mathrm{~b}-87 \mathrm{~b}$ is the text of Daläil al-Khayrāt. On ff. 88a-236a are texts that belong to the ritual context of al-Ǧazūlì's prayer book. The text block, measuring $10 \times 9.5 \mathrm{~cm}$, is kept in a red full-leather Islamic binding with flap, showing intensely worked gilded ornamentation. The luxury binding is in traditional Maghribı style. It can be seen, for instance, on Ms Leiden Or. 1335, Ms Doha, Qațar National Library No. 10522, and many others, both for the Qur'än and other texts.

The Berlin copy is a princely Moroccan manuscript. On 1 Ğumādā I 1213 (1798), it was made into an endowment for the burial chamber in the Prophet's mosque in Medina (al-huğra al-nabawiyya, a term synonymous with al-rawda al-mubāraka). Visitors to the Prophet's tomb in Medina would often leave beautiful copies of the Qurān and the Daläil al-Khayrät in the chamber as endowments. Al-Batanūnī, who visited the mosque in 1327/19o9, writes that many Qur'ānic manuscripts and printed editions were donated by visitors, 'and next to these there were many copies of the Daläil al-Khayrāt'. ${ }^{49}$ The particularly luxurious production of the Berlin manuscript attests to it being a socially important object. The founder of this endowment, the wäqif of the Berlin manuscript, is Mūsā, the son of the Sharîf Muhammad III b. 'Abdallāh

48 A detailed description in Abid, Dalä'il, vol. II, pp. 192-196, her siglum ND5O.

49 Al-Batanūnī, al-Riḥla, p. 241. 


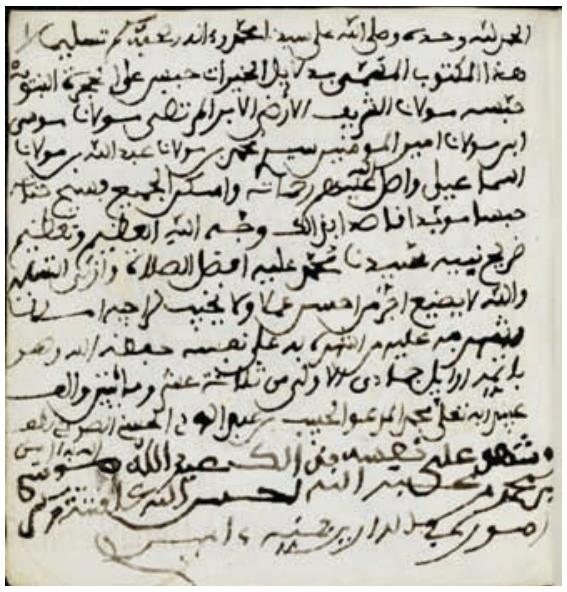

FIGURE 8

The waqfiyya, dated 1 Ğumādā I 1213 (11 October 1798), confirming the deposition of this manuscript of Daläil al-Khayrāt in the Prophet's burial chamber in Medina. Lines 12-13 contain the signature of the Moroccan prince Mūsa, the son of Sultan Muhammad III b. 'Abdallāh MS BERLIN, STAATSBIBLIOTHEK, OR. OCT. 240, F. $1 \mathrm{~A}$

(Sultāan on Morocco, who reigned 1171-1204/1757-1790). ${ }^{50}$ The text of the waqfiyya (f. 1a) is written in a regular scholar's hand, is signed by one or more signatories and contains the following information (figure 8):

Arabic text:

$$
\begin{aligned}
& \text { الحمد الله وحده وصلى الله على سيدنا محمد وءاله وصحبه وسلم تسليما } \\
& \text { هذا المكتوب المسمى بدلايل الخيرات حبس على الخجرة النبوية }
\end{aligned}
$$

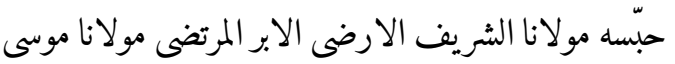

$$
\begin{aligned}
& \text { ابن مولانا امير المومنين سيدى محمد بن مولانا عبدالله بن مولانا } \\
& \text { اسماعيل واصل الله عليهم رحماته واسكن الجميع فسيح جناته } \\
& \text { حبسا موبّدا قاصدا بذالك وجه الله العظيم وتعظيم } \\
& \text { ضريح نبيه سيدّا محمّ عليه افضل الصلاة وازكى التسليم } \\
& \text { والله لا يضيع اجر من احسن عملا ولا يخيب لراجيه املاتا }
\end{aligned}
$$

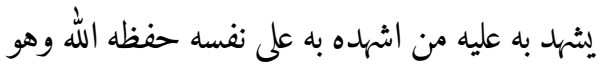

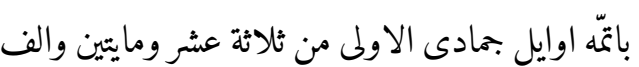

$5^{\circ}$ See the genealogy of the 'Alawī or Filāīi Sharīfs, the ruling dynasty of present-day Morocco, in C.E. Bosworth, The New Islamic Dynasties. A Chronological and Genealogical Manual. Edinburgh: Edinburgh University Press, 1996, No. 21. 


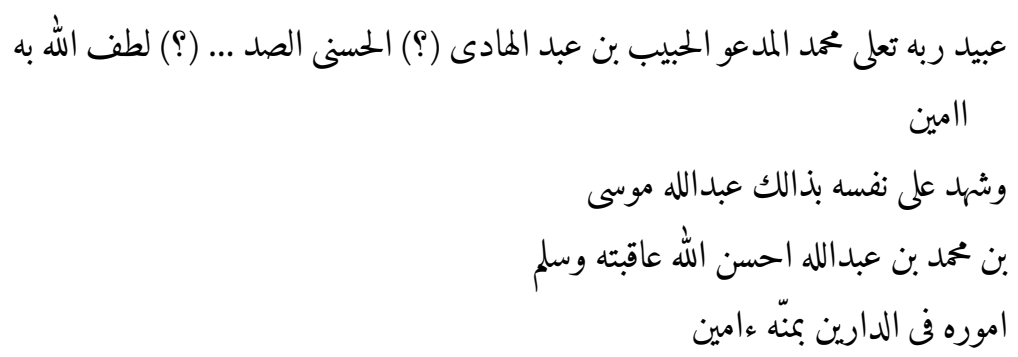

Translation:

'Praise be to God alone. May God bless our Lord Muhammad and his family and his companions and grant them peace.

This manuscript, entitled Dalāil al-Khayrāt, was deposited in the burial chamber of the Prophet. It was deposited by our noble, most gracious, most obedient, most content Lord, our Lord Mūsa the son of our Lord, the Prince of the Believers, Sīdī Muhammad, the son of our Lord 'Abdallāh, the son of our Lord Ismā'īl, may God bring him His mercies and may He give all of them a dwelling in his spacious gardens. The deposition is of permanent nature, and is intended to be done for the sake of God, the Great, and in glorification of the mausoleum of His Prophet, our master Muhammad, may he receive the best blessing and the purest wishes of peace. God does not let the reward ${ }^{51}$ for whom does the work well go lost, nor does he disappoint the one who puts his hope in Him. May He bear witness to this in the way I bear witness to this, as I do that myself, may God preserve him. Thus done on the first day of Ğumādā I of 1213 by the insignificant servant of his elevated Lord, Muhammad, called the beloved, the son of 'Abd al-Hādī (?) al-Hasanī al-Ṣad ... (?), may God be kind to him. Amen.

Thus has witnessed to that concerning himself, the servant of God Mūsā b. Muhammad b. 'Abdallāh, may God make his end good and may He by His favour make his affairs in the two abodes faultless. Amen.'

All texts following the waqfyya are luxuriously executed, both in terms of illuminations and calligraphy.

(1) ff. 1b-6a. The ornamental addition that precedes the text of Dalāil alKhayrāt. It contains:

51 الله لا يضيع اجر is Qurānic, the passage occurs four times in the Qurān. 
ff. $1 \mathrm{~b}, 3 \mathrm{~b}-4 \mathrm{a}$. The pedigree (shağara) of the Prophet Muhammad, preceded by the ten names of al-Ashara al-Mubashshara written inside circles (ff. 2a3a). The Prophet's pedigree on $\mathrm{ff} .3 \mathrm{~b}-4 \mathrm{a}$ is written in Maghribi thuluth script in boustrophedon:

$$
\begin{aligned}
& \text { بم الله الرحمن الرحيم صلى اله على محمد وءاله | شجرة خير الانام | المى ابيناء آدم على نبينا | }
\end{aligned}
$$

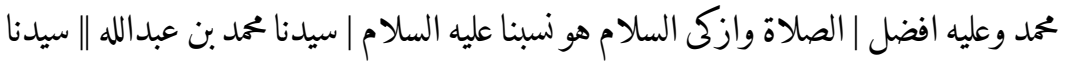

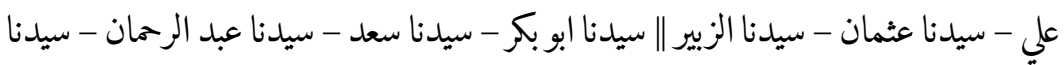

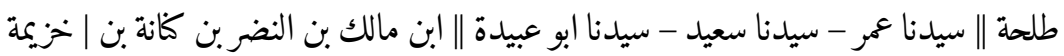

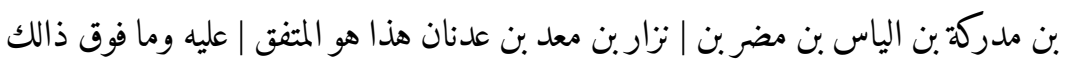

$$
\begin{aligned}
& \text { بن اد بن ادد بن | مسلح بن يعرب بن يسحن بن الممسع | بن نايت بن اسماعيل بن ابرهيم عليهما }
\end{aligned}
$$

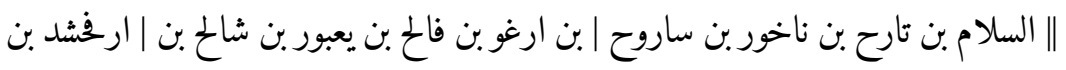

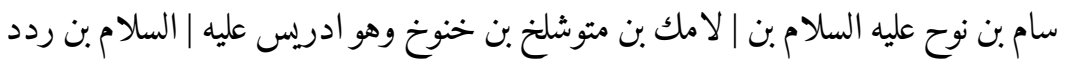

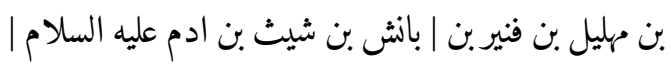

ff. $4 \mathrm{~b}-5 \mathrm{a}$. The twenty-one expeditions (ghazawāt) of the Prophet Muhammad:

$$
\begin{aligned}
& \text { غزواته صلى الله احدى وعشرون | غزوة ودان - غزوة عين فريشة - غزوة بدر - غزوة }
\end{aligned}
$$

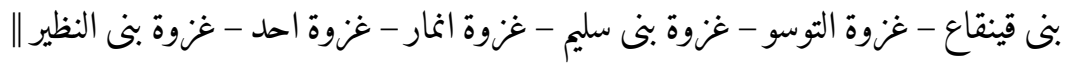

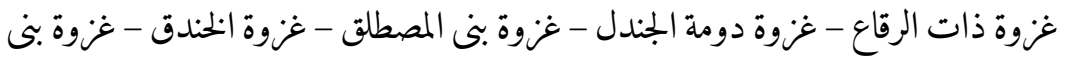

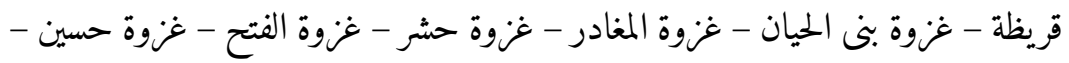

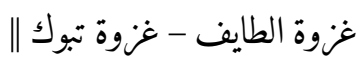

ff. 5 b-6a. The images of the sanctuaries of Mecca (f. 5 b) and Medina (f. 6a), executed in topographical style combined with the flat projection of several of its details (figures 9 and 10), which are described in minute script. Both drawings are highly stylized.

f. 5 b. Above the image of the mosque in Mecca (figure 9) is a cartouche with the Qur’ānic text (5:97):جعل الله الكعبة البيت الحرام قياما للناس. The inner court of the mosque is an approximate square. Inside the court, details are described with legends, indicated hereunder in italics. The orientation is East (mashriq) on top, West (maghrib) at the bottom, South ( ğunūb) to the right, and North (shamāl) to the left. All seven minarets are described as ma'dhana, with 'minaret' written here مادنه. A central circle contains the square of the Ka'ba 


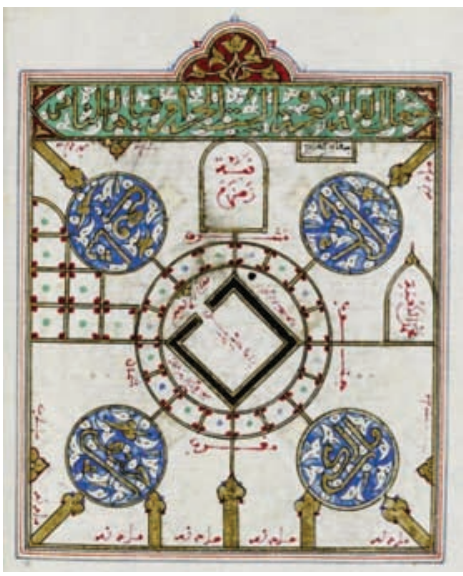

FIGURE 9

The Mecca image as it occurs in the ornamental addition to a luxury manuscript, in the part preceding the text of Dalāil al-Khayrāt, from the Maghrib, copied before 1213/1798 MS BERLIN, STAATSBIBLIOTHEK, OR. OCT. 240, F. $5^{\text {B }}$

with its four corners matching the cardinal points exactly, and its entrance in the North-East wall, called Bāb Ğibrïl. To the North-East is the Maqām Ibrāhìm, to the South-East is the black stone, al-Hağar al-Aswad, indicated as a black dot; to the North-West is the Mizäb al-Rahma. The right angles of the corners of the square are divided into two and contain blue circles with white floral motifs that carry the names of the four Law schools written in gold: Shäfi $\bar{\imath}$ (North-East); Hanbalī (South-East); Mālikī (South-West); and Hanafi (NorthWest). Pointing eastward is the Qubbat Zamzam. Slightly South of that is a location called siqāyat al-ḩăğğ, the place for distributing water to the pilgrims. At three directions the word $B \bar{a} b$, gate, is written near the frame of the inner court. Each gate is indicated with a small pile of three golden rocks. The square of the court is divided into two by a horizontal line. To the far South is a niche called makhzan al-Ka'ba, the treasury of the Ka'ba. To the far North is a large drawing of a pulpit.

f. 6a. Above the image of the mosque Medina (f. 6a, figure 10) is a cartouche with the hadith text: ما بين قبرى ومنبرى روضة من رياض الجن 'Whatever is between my grave and my pulpit, is a garden of Paradise'. The inner court of the mosque is an approximate square. Inside the court, details are described with legends, here indicated in italics. The orientation is $90^{\circ}$ different from that in the Meccan image, with South (ğunūb) on top, North (shamāl) at the bottom, West (maghrib) to the right, and East (mashriq) to the left. In the centre of the court are two partly overlapping rectangles of different dimensions. The eastern rectangle is a walled space that contains the burial chamber, here shown as a niche with a hanging lamp and the three tombs (the Prophet, Abū Bakr, 'Umar). These have legends: Qabr al-Nabīal-Salām 'alayhi (قبر النى السعليه), Qabr Abī Bakrradiya Allāh 'anhu, Qabr 'Umar radiya Allāh 'anhu. Near the South-West corner of the 


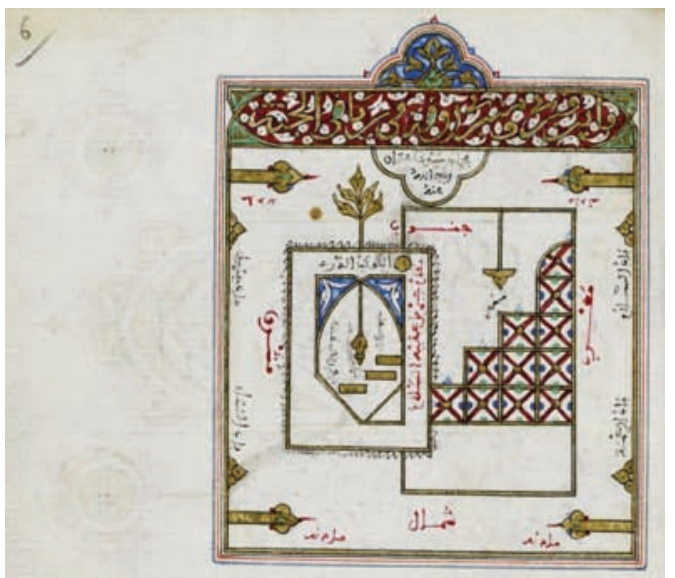

FIGURE 10

The Medina image as it occurs in the ornamental addition to a luxury manuscript, in the part preceding the text of Dalā'il al-Khayrāt, from the Maghrib, copied before 1213/1798 MS BERLIN, STAATSBIBLIOTHEK, OR. OCT. 240 , F. 6 A

chamber is a small circle in gold with the legend al-kawkab al-durrī, 'the Brilliant Star'. West of the burial chamber, but within the enclosure is Maqām Ǧibrīl 'alayhi al-Salām. The western rectangle contains the pulpit, minbar, seen from the side, with four steps. To the far South, in the centre, is mihrāb Sayyidina 'Uthmān radiya Allāh 'anhu, the prayer niche ascribed to the third caliph, 'Uthmān b. 'Affān. Within the frame around the courts are four minarets, ma'dhana, and next to each minaret is a gate: Bāb al-Salām (South-West); Bāb al-Rahma (North-West); Bāb al-Nis $\bar{a}^{\prime}$ (North-East); and Bāb Ğibrīl (South-East). Any reference to Fātima is absent from the legends. A plant or tree is growing South of the enclosure of the burial chamber. It has no legend. It is evidently meant to be Fāțima's garden. ${ }^{52}$

(2) ff. 6b-87b. Text of Dalāil al-Khayrāt by al-Ǧazūīi.

f. 6 b. Title-page with incipit, a full-page illumination with three cartouches:

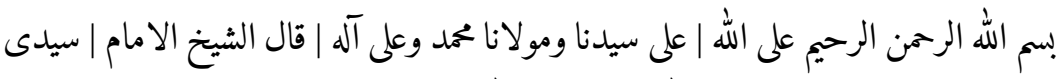

$$
\begin{aligned}
& \text { محمد بن سليمان الجزولى | رحمه الله تعالى | الحمد الله الله }
\end{aligned}
$$

ff. 17a-19a. Description of the 'Blessed Garden', șifat al-Rawḍa al-Mubāraka, with an introduction (f. 17a), the Medinan double image of the burial chamber (f. 17b) and the minbar (f. 18a), the two anecdotes concerning Jesus's burial place (f. 18b), and the dream of Â'isha about the future occupants of the chamber (ff. 18b-19a). The two spaces in the Medinan mosque are depicted as single chambers.

$5^{2}$ Bustān al-Sayyida Fāțima, as shown in a map by al-Batanūnī, al-Riḥla, between pp. 243244 . 


\section{FIGURE 11}

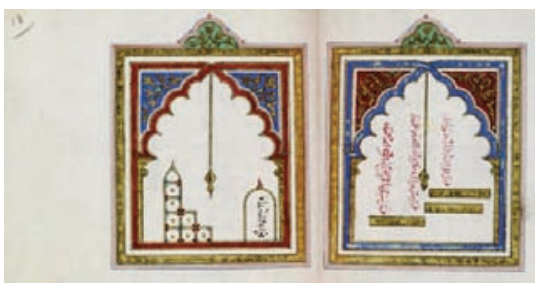

The Medinan double image as it also occurs in luxury manuscripts of Dalāil al-Khayrāt from the Maghrib. The burial chamber (f. 17b, right) and the minbar and mihrāb (f. 18a, left). Ms Berlin, Staatsbibliothek, Or. oct. 240, copied before 1213/1798. In the original manuscript the individual pages are separated by protecting leaves. These have been omitted here.

ff. 17b-18a. The Medinan double image (figure 11).

f. $17 \mathrm{~b}$. The burial chamber is drawn as a niche, set within a frame. In its centre a lamp hangs down. Under the niche one can see three tombs, each with legends: Qabruhu șallā Allāh 'alayhi wa-sallam (the Prophet), Qabr Sayyidinā Abì Bakr radiya Allāh 'anhu (Abū Bakr, the first caliph), and Qabr Sayyidinā 'Umar b. al-Khatțāb radiya Allāh 'anhu ('Umar, the second caliph).

f. 18a. A niche set within a frame contains the minbar, which is shown from the side, without legend, Next to it is the prayer niche, described as mihrāb alsalāt.

(3) On ff. 88a-235b, after the text of the Dalāil al-Khayrāt, come the texts that belong to its ritual context, and that one often encounters in North African convolute manuscripts with the Dalāil al-Khayrāt. ${ }^{53}$ All of these have been written by the same copyist and illuminated by the same illuminator, who also made the text of Dalāil al-Khayrāt. They are: the Burda by al-Būṣirī (ff. 88a105b); the Hizb al-Baḥr by al-Shādhilī (ff. 106a-108b); al-Hizb al-Kabīr by alShādhilī (ff. 109a-120a); the Hizb by al-Nawawī (ff. 120a-122b); the Salāt of Ibn Mashshīsh (ff. 123a-124b); the Wažifa by Ibn Zarrūq (ff. 124b-13ob); the Hizb al-Falāh by al-Ğazūlī himself (ff. 131a-132a); the Hafı̌ a by Ibn Zarrūq (ff. 132b133b); the Hizb by 'Abd al-Qādir al-Ǧīlānì (ff. 134a-b); and, finally, the Kiṭāb al-Hișn al-Hașin min Kalām Sayyid al-Mursalīn by al-Ǧazarī (ff. 135b-235b). This is concluded with an illuminated page without text (f. 236a).

The Mecca-Medina double image of the ornamental additions to the subgroup of heavily illuminated manuscripts of Daläil al-Khayrāt that I have defined is not exclusive for manuscripts. The topographical representation of the sanctuaries, especially of that of Mecca, can also be seen on Iznik tiles that would be approximately as old as the oldest known manuscript of the illuminated subgroup of Dalā'il manuscripts. ${ }^{54}$

53 Ms Leiden, Ter Lugt Collection No. 245 is a convolute volume from Tunisia, with a significantly different set of texts accompanying the Daläil al-Khayrāt.

54 Ms Dublin, Chester Beatty Library 4223, dated 1048/1638-1639. An example of such a tile from Mecca, estimated to date from the 17 th century, is shown in Benaki Museum. A Guide 
The sheer popularity of the Daläil al-Khayrāt in space and time has given occasion to illustrations in manuscripts other than those described here as the 'ornamental addition'. A few may be mentioned here. In a 2oth-century manuscript from India, now kept in Kuala Lumpur, we see a set of illustrations, some of which are well-known, others unusual: the Great Mosque of Mecca (f. $7 \mathrm{a}$ ), the Prophet's Mosque in Medina (f. 8a), a view of Baqī al-Gharqad, the Medinan cemetery (f. 8b), another image of a mosque possibly that in Kalyānī, India (f. 1ob), and al-Huğra al-Maymūna, the burial chamber in the Prophet's Mosque in Medina (f. 11a). The latter shows the three moons that 'Â'isha saw in her foretelling dream. ${ }^{55}$

Another exceptional manuscript is the Malayo-Arabic convolute Ms Leiden, University Library Or. 1751. It is lavishly illustrated. It was copied in Bandar Natal, Sumatra, on 29 Shawwāl 1229 (1814) and is now known as "the prayer book of Imam Bonjol", even if there is no documented connection between the manuscript and this historical personality, who lived 1772-1864. On pp. 127128 the manuscript has a Mecca-Medina double image (ff. 68b-69a) outside the text of Daläil al-Khayrāt. It has a detailed Medinan image inside the text of Daläil al-Khayrät, on f. 183a. It also has an image of Baqī' al-Gharqad, the cemetery outside Medina (f. $69 \mathrm{~b}$ ), and many more images that have a religious or magical dimension.

Yet another unusually illustrated manuscript of the Daläil al-Khayrāt is MS Paris, BnF Arabe 6869. It is an incomplete undated sub-Saharan copy from the 19th century. Its earliest documented provenance is Abidjan, ca. 1921. In the BnF catalogues it does not seem to be recognized as an incomplete manuscript of alĞazūlì's prayer book. ${ }^{56}$ Apart from a number of stunning calligraphic pages, the

to the Museum of Islamic Art. Athens: Benaki Museum, 2006, p. 156, No. 209, but there are many more images of such tiles available. More references in Abid, 'Birth', note 45. See also Deniz Beyazit, 'Paths of Prayer', in the present volume.

55 Jan Just Witkam, 'The Former ISTAC Library in Kuala Lumpur and its Islamic Manuscripts. Travel Notes', in Journal of Islamic Manuscripts 8 (2017), pp. 281-339, pp. 298-302, figs. 2, 3 . When I examined them, the ISTAC manuscripts had no proper class marks. This volume I gave the class mark 'Ar. Cat., vol. 1, p. 13, No. 61'.

$5^{6}$ Gallica https://gallica.bnf.fr/ark:/12148/btvıb8406156n.r=Arabe-6869?rk=21459;2\#; Guesdon \& Vernay-Nouri, L'art du livre arabe, p. 69, No. 39 (described by Annie VernayNouri). A detailed description will appear in my Paris travel notes of 2005. See Yvette Sauvan, M.-G. Balty-Guesdon, T. Tamari, Catalogue des manuscrits arabes. Index 68367214. Paris 1987, p. 29. See for these additional images Jan Just Witkam, From codicology to the history of the Islamic book. Leiden: Ter Lugt Press, 2021, pp. 18-2O. 
manuscript has a small collection of illustrations, mostly composed of geometrical elements. These show al-Burāq, the Prophet's riding animal (f. 84a), two images of the Prophet's footprint (ff. 84b, 85a), the Prophet's house in Mecca (f. 85b), a niche (meaning not clear, f. 86a), the grave of the Prophet, with mention of the names of the four angels, and the first four caliphs (f. 86b), the Kaba (f. 87a), the Great Mosque of Mecca (f. 87b), the Prophet's Mosque in Medina (f. 88a), the Prophet's house in Medina (f. 88b), the mountain of the bird in Shinnīs, from where the copyist originates (f. 89a), and, finally, the weighing scales that will be used on the Day of Resurrection (f. 8gb).

These three examples, that only have come to my knowledge accidentally, show that the illustration history of the Daläil al-Khayrät is far more complex than we think. It is evident that more research has to be done on this. One step in that research is the disconnection of the text of the Dalāil al-Khayrāt from the ornamental addition, that has been the subject of the present article.

\section{Bibliography}

\section{Conspectus of Manuscripts}

If provided with an asterisk, the manuscript has been illustrated in the article.

Berlin, Staatsbibliothek Or. oct. 240*

Berlin, Staatsbibliothek Petermann II Nachtrag 12

Doha, Qațar National Library No. $105^{22}$

Doha, Qațar National Library No. 30003*

Dublin, Chester Beatty Library 4223

Dublin, Chester Beatty Library 4240

Dublin, Chester Beatty Library 5459

Fes, Qarawiyyīn Library 3226

Kuala Lumpur, Islamic Art Museum

Malaysia (IAMM) 2011.1.23

Kuala Lumpur, ISTAC, unspecified

Istanbul, Collection Ömer Koçyiğit*

Leiden, University Library Or. 1335

Leiden, University Library Or. $175^{1}$

Leiden, University Library Or. 4826

Leiden, University Library Or. 7057a

Leiden, University Library Or. 22.958
Leiden, Ter Lugt Collection No. $49^{*}$

Leiden, Ter Lugt Collection No. 245

Leipzig, University Library Vollers 65

London, British Library, not specified

München, Bayerische Staatsbibliothek,

Cod. Arab. $285^{2}$

New York, Columbia University, Rare

Book and Manuscript Library Or. 117

New York, Metropolitan Museum, 2017.301

New York, Public Library, Arabic 5

Paris, BnF Arabe 1180

Paris, BnF Arabe 1181

Paris, BnF Arabe 1185

Paris, BnF Arabe 1192

Paris, BnF Arabe 1270

Paris, BnF Arabe 6869

Paris, BnF Arabe 6983 [Réserve 1517] * 
Paris, BnF Arabe 7170

Paris, BnF Arabe 7253

Paris, Musée Quai Branly 74.1962.0

Philadelphia, US, Library Company 69097 D

Rabat, Bibliothèque nationale 399

Rabat, Bibliothèque nationale $\mathrm{G} 35^{6}$
Rabat, Hasaniyya 3227

Rabat, Hasaniyya 12301

Rijswijk, Collection P.S. van Koningsveld Toronto, Aga Khan Museum AKM 535

Tunis, Bibliothèque nationale 3630

Vienna, Österreichische Nationalbibliothek Mixt. 1876

\section{Printed and Unpublished Sources}

Hiba Abid, Les Dalā'il al-Khayrāt d'al-Jazūlì (m. 869/1465). La tradition manuscrite d'un livre de prières soufi au Maghreb $d u X^{e} / X V I^{e}$ au XIII ${ }^{e} / X I X^{e}$ siècles. Thèse de doctorat de Codicologie et d'Histoire de l'art islamiques. Paris 2017, unpublishd thesis. vol. I (Texte) and vol. II (Catalogue des manuscrits). [Not seen: vols. III and IV].

Hiba Abid, 'Material Images and Mental Ziyāra: Depicting the Prophet's Grave in North African Devotional Books (Dalā'il al-Khayrāt)', in: Journal of Material Cultures in the Muslim World 1 (2020), pp. 331-354.

Hiba Abid, 'The Birth of a Successful Prayer Book. The Manuscript Tradition of the Dalāil al-Khayrāt in North Africa', in the present volume.

Arthur J. Arberry, The Chester Beatty Library. A Handlist of the Arabic Manuscripts. Volume v. MSs. 4001-4500. Dublin: Hodges, Figgis \& Co., 1962.

Arthur J. Arberry, The Chester Beatty Library. A Handlist of the Arabic Manuscripts. Volume viI. MSs. 5001-5500. Dublin: Hodges, Figgis \& Co., 1964.

Muḥammad Labīb al-Batanūnī, al-Riḥla al-Hiğāziyya li-Walī al-Níam al-Hāăğğ Abbās Hilmī Bāshā al-Thānī Khid̄̄w Mișr. Cairo²: Maṭba'at al-Ǧamāliyya, 1329 (1911).

Benaki Museum. A Guide to the Museum of Islamic Art. Athens: Benaki Museum, 2006. Deniz Beyazit, 'Paths of Prayer in Ottoman North Africa. The Met's Dalāil al-khayrāt 2017.301 in context', in the present volume.

Deniz Beyazit, [description of Ms Toronto, Aga Khan Museum AKM 535]: https://www .agakhanmuseum.org/collection/artifact/dala-il-al-khayrat-prayer-book-akm535

C.E. Bosworth, The New Islamic Dynasties. A Chronological and Genealogical Manual. Edinburgh: Edinburgh University Press, 1996.

Guy Burak, 'Collating The Signs of Benevolent Deeds. Muhammad Mahdī al-Fāsì's Commentary on Muhammad al-Jazūlī's Dalāil al-Khayrāt and Its Ottoman Readers', in: Philological Encounters 4 (2018), pp. 135-157.

William Cureton, Catalogus codicum manuscriptorum orientalium qui in Museo Britannico asservantur. Pars secunda. Codices arabicos amplectens. London: British Museum, 1846.

Yana van Dyke, 'A Technical Study of a 17th-Century Manuscript of Muhammad Bin Sulaymān al-Jazūlī's Dalā'il al-Khayrāt', in the present volume. 
Muhammad al-Mahdī b. Aḥmad 'Alī b. Yūsuf al-Fāsī al-Qașrī, Mațāli' al-Masarrāt biĞalā’ Dalāil al-Khayrāt. Ed. Hasan Aḥmad 'Abd al-'Āl. Al-Dār al-Bayḍā: Dār alRashād al-Hadītha, 1426/2005.

GAL = Carl Brockelmann, Geschichte der arabischen Litteratur. Leiden 1943-1949 (2 volumes Geschichte), 1937-1942 (3 volumes Supplement).

Margaret S. Graves, Benoît Junod, Gérard Friedli, Aga Khan Trust for Culture, Aga Khan Museum, Architecture in Islamic Arts: Treasures of the Aga Khan Museum. Geneva: Aga Khan Trust for Culture, 2011 [Published to accompany an exhibition held at the State Hermitage Museum, St. Petersburg, Russia, 2 December 2011-26 February 2012; the Islamic Arts Museum Malaysia, Kuala Lumpur, 7 April-29 June 2012; and the Asian Civilisations Museum, Singapore, 19 July-19 October 2012].

Marie-Geneviève Guesdon \& Annie Vernay-Nouri (eds.), L'art du livre arabe. Du manuscrit au livre d'artiste. Paris: Bibliothèque nationale de France, 2001.

Jazūlī, Dalāil al-hairāt und andere Texte: "Anthologie”. Vollständige Faksimile-Ausgabe im Originalformat des Codex Vind. Mixt. 1876 aus dem Besitz der Österreichischen Nationalbibliothek. Ed. Tarif al Samman. Graz: Akademische Druck und Verlagsanstalt, 1987. 2 vols (Faksimile, Kommentar).

P.S. van Koningsveld, The Tomb of the Prophet. Attitudes and Discussions around a Major Religious Symbol in Islam. Leiden: Leiden University, 2007. [with Arabic translation by Mohammed Ghaly, and a selective autobibliography of the author]

P.Sj. van Koningsveld, 'Puriteinen niet wars van plaatjes profeet. Studie naar afbeeldingen van Mohammed in gebedenboek', in: Mare di Libri, December 4, 2003 , p. 6.

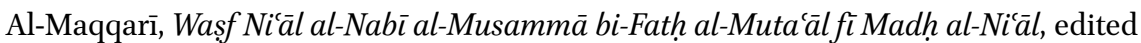
by 'Alī 'Abd al-Wahhāb \& 'Abd al-Mun'im Farağ Darwīsh. Cairo: Dār al-Qāḍī 'Iyāọ lil-Turāth, n.d.

Al-Maqqarī, Fatḥ al-Mutáäl fì Madḥ al-Ni‘āl, edited by Aḥmad Farīd al-Mazīdī. Beirut: Dār al-Kutub al-'Ilmiyya, n.d.

Simon O'Meara, The Ka'ba Orientations. Readings in Islam's Ancient House. Edinburgh: Edinburgh University Press, 2020.

al-Rașșā', al-Khamsami’a Ṣalāt 'alā al-Nabī. Ed. Nizār Ḥammādī. al-Kuwayt: Dār al-Diyā' lil-Nashr wal-Tawzī', 1433/2012.

Charles Rieu, Supplement to the Catalogue of the Arabic Manuscripts in the British Museum. London: The British Museum, 1894.

Nurul Iman Rusli, Heba Nayel Barakat and Amira Salleh, Dala'il al-Khayrat. Prayer Manuscripts from the 16th-19th Centuries. Kuala Lumpur: Islamic Art Museum Malaysia, 2016.

De Slane, Bibliothèque nationale. Département des manuscrits. Catalogue des manuscrits arabes. Paris: Imprimerie nationale, 1883-1895.

Ahmed Toufiq \& M.-G. Guesdon (eds.), Dalāil al-Khayrāt wā Shawāriq al-Anwār fì aṣȘalāt 'alā an-Nabīal-Mukhtār et autres textes panégyriques et d'invocation. Facsimilé 
du manuscrit $n^{\circ} \mathrm{G} 35^{6}$ de la Bibliothèque nationale du Royaume du Maroc (ancienne Bibliothèque Générale et Archives). Introduction et commentaire, Rabat, Royaume du Maroc, Ministère des Habous et des Affaires Islamiques, 2003.

Jan Just Witkam, From codicology to the history of the Islamic book. Keynote speech given on 27 August 2021, at the end of the Arabic Manuscripts Workshop organized by Princeton and UCLA. Leiden: Ter Lugt Press, 2021.

Jan Just Witkam, 'The Former ISTAC Library in Kuala Lumpur and its Islamic Manuscripts. Travel Notes', in Journal of Islamic Manuscripts 8 (2017), pp. 281-339.

Jan Just Witkam, 'The Battle of the Images. Mecca vs. Medina in the Iconography of the Manuscripts of al-Jazūlī's Dalā'il al-Khayrāt', in Judith Pfeiffer \& Manfred Kropp (eds.), Technical Approaches to the Transmission and Edition of Oriental Manuscripts = Beiruter Texte und Studien, No. 111 (Beirut: Orient Institut, 2007), pp. 67-82 (text), 295-300 (illustrations).

Jan Just Witkam, Vroomheid en activisme in een islamitisch gebedenboek. De geschiedenis van de Dalāil al-Khayrāt van al-Ǧazūlī. Leiden: Legatum Warnerianum, 2002. 